IZA DP No. 5411

Can State Language Policies Distort Students' Demand for Higher Education?

Alexander Muravyev

Oleksandr Talavera

December 2010 


\title{
Can State Language Policies Distort Students' Demand for Higher Education?
}

\author{
Alexander Muravyev \\ IZA, DIW Berlin \\ and St. Petersburg University \\ Oleksandr Talavera \\ University of East Anglia
}

\section{Discussion Paper No. 5411 \\ December 2010}

\author{
IZA \\ P.O. Box 7240 \\ 53072 Bonn \\ Germany \\ Phone: +49-228-3894-0 \\ Fax: +49-228-3894-180 \\ E-mail: iza@iza.org
}

\begin{abstract}
Any opinions expressed here are those of the author(s) and not those of IZA. Research published in this series may include views on policy, but the institute itself takes no institutional policy positions.

The Institute for the Study of Labor (IZA) in Bonn is a local and virtual international research center and a place of communication between science, politics and business. IZA is an independent nonprofit organization supported by Deutsche Post Foundation. The center is associated with the University of Bonn and offers a stimulating research environment through its international network, workshops and conferences, data service, project support, research visits and doctoral program. IZA engages in (i) original and internationally competitive research in all fields of labor economics, (ii) development of policy concepts, and (iii) dissemination of research results and concepts to the interested public.
\end{abstract}

IZA Discussion Papers often represent preliminary work and are circulated to encourage discussion. Citation of such a paper should account for its provisional character. A revised version may be available directly from the author. 
IZA Discussion Paper No. 5411

December 2010

\section{ABSTRACT \\ Can State Language Policies Distort Students' Demand for Higher Education?*}

This paper takes advantage of a recent policy experiment in Ukraine's secondary education system to study the effect of stricter requirements for proficiency in the state language on linguistic minority students' demand for, as well as opportunities to pursue, further studies at the university level. The reform that we consider obligated all minority students, including those studying in public schools with a full cycle of education in minority languages, to take a standardized school exit test (which is also a university entry test) in Ukrainian, the state language, thus denying them previously granted access to translated tests. Using schoollevel data and employing the difference-in-difference estimator we find evidence that the reform resulted in a decline in the number of subjects taken by minority students at the school exit test. There was also a notable shift in the take-up of particular subjects, with fewer exams taken by minority students in more linguistically-demanding subjects such as History, Biology, and Geography, and more exams taken in foreign languages and Math. Overall, our results suggest some distortions in the accumulation of human capital by linguistic minority students induced by the language policy.

JEL Classification: $\quad 128, \mathrm{~J} 15$

Keywords: language policy, economics of minorities, education, Ukraine

Corresponding author:

Alexander Muravyev

IZA

P.O. Box 7240

53072 Bonn

Germany

E-mail: muravyev@iza.org

\footnotetext{
* We are grateful to Hartmut Lehmann and participants of the IZA brownbag seminar for useful comments and suggestions.
} 


\section{Introduction}

Language policies, which promote or discourage the use of a particular language or set of languages, have been common in many countries throughout history (Spolsky 2004). A prominent example is France, whose language policies date back to the early $16^{\text {th }}$ century and have been "central to the history of state and nation-building” (Jacob and Gordon, 1985, p. 106). More recent examples of language policies include New Zealand's government support to the revival of Maori (Spolsky 2003), promotion of French in Quebec at the expense of English (MacMillan 2003), restrictions on the use of Russian in the public sphere in Estonia and Latvia (Hughes 2005), and policies of multilingualism in the European Union (Gazzola 2006).

Until recently, economic considerations have rarely played a major role in the design of language policies (Grin 2006). ${ }^{1}$ This is despite numerous links between languages and economic outcomes established in the economics of language literature which dates back to Marschack (1965). There is, for example, extensive evidence that immigrants' proficiency in the dominant language strongly affects their labor market outcomes (McManus, Gould, and Welch 1983; Chiswick 1991; Dustmann and Fabbri 2003; Bleakley and Chin 2004). A growing related literature analyzes the effects of language proficiency for native-born bilinguals (Fry and Lowell 2003; Henley and Jones 2005; Chiswick and Miller 2007). Furthermore, a number of studies from the business literature also suggest that languages play an important role, for example, in advertising and corporate communication (e.g., Puntoni, de Langhem, and van Osselaer 2009; Krishna and Ahluwalia 2008; Marschan-Piekkaria, Welch, and Welch 1999). On the macro-level, there is evidence that linguistic distances affect international trade (Hutchinson 2005; Melitz 2008).

Similarly, evaluation of language policies has rarely been conducted using the tools of modern economics that emphasize the issues of identification and measurement (Grin 2003, 2006). Recent important contributions to this field include Grin and Vaillancourt (1999), Ginsburgh, Ortuño-Ortin and Weber (2005), Fidrmuc and Ginsburgh (2007), and AspachsBracons et al. (2008), among others. In particular, Grin and Vaillancourt (1999) develop a cost-effectiveness evaluation of minority language policies in Wales, Ireland and the Basque Country. Ginsburgh et al. (2005) and Fidrmuc and Ginsburgh (2007) suggest that language policies should balance the benefits of linguistic "standardization" on the one hand and the

\footnotetext{
${ }^{1}$ Grin (2006 p.77) suggests that "policy discourses about language have tended to rely on one of three main perspectives: a legal one, in which language policy often takes the form of the enunciation of language rights in given contexts; a culturalist one, in which languages are mostly seen as manifestations of culture, confining policy to a set of measures affecting corpus or, at best, support for literary creation or publication; and an educational one, focusing on language teaching”.
} 
costs of "disenfranchisement" of linguistic minorities on the other hand and propose a framework for choosing an optimal language policy for the European Union, which would balance the cost of translation into multiple official languages and the cost of disenfranchisement of some linguistic groups. Exploiting the 1983 reform of education in Catalonia and the Basque Country, which introduced bilingual education in schools, AspachsBracons et al. (2008) find a significant effect of the compulsory language policy on the development of schoolchildren's individual identity.

In this paper we take advantage of a recent natural experiment in Ukraine's secondary education system to study potential side effects of language policies that impose stricter requirements for proficiency in the state language. The reform that we consider was planned for the 2009/2010 academic year and obligated all linguistic minority students, including those studying in public schools with full cycle of education in minority languages, to take a standardized school exit test (which is also a university entry test) in Ukrainian, the state language, thus denying them previously granted access to translated tests. Our focus is on the effect of this policy change on linguistic minority students' demand for, as well as opportunities to pursue, further studies at the university level, as measured by the results of the standardized school exit test.

Our empirical analysis uses school-level data from the 2009 and 2010 standardized tests and employs the difference-in-difference estimator, a common tool in program evaluation studies. Although a key issue in the language policy of modern Ukraine is the status of Russian, we drop schools with Russian as the language of instruction and focus on the performance of Hungarian and Moldovan/Romanian schools relative to the performance of Ukrainian ones. The omission of Russian schools purifies our experiment as Ukrainian and Russian are closely related and easily mixed; moreover, it is often difficult to separate Russian schools from Ukrainian ones in the data.

Our main findings are as follows. We find fairly strong evidence that the change in the language policy has resulted in a decline in the number of subjects taken by minority students at the school exit test. There is also a notable shift in the take-up of particular subjects, with fewer exams taken by minority students in more linguistically-demanding subjects such as History, Biology, and Geography, and more exams taken in foreign languages and Math. This has immediate consequences for access of minority students to further education at the university level as entry to different universities and different fields of study require tests in different subjects. We also find some evidence that minority students improved their proficiency in Ukrainian between 2009 and 2010, although this effect is not necessarily fully 
attributable to the policy change analyzed. Overall, our results suggest important distortions in the accumulation of human capital by linguistic minority students induced by the language policy that imposed stricter requirements for proficiency in the state language.

We believe that our paper is far more than a case study of a particular reform in a particular country. By documenting important side effects of strict language policies it provides a general contribution to the economics of language literature. Further strengths of our paper are related to the identification strategy. In particular, the uniqueness of our setup allows us to analyze the effect of language policies in the non-immigrant environment and in the absence of large cultural differences between the title nation and linguistic minorities. Also, the use of the difference-in-difference estimation technique in our paper makes possible estimation of the causal effect of the policy change on education outcomes of minority students.

Our study is directly related to the rapidly growing strand of economics literature that analyzes languages and language policies (e.g., Wickström 2005; Ortega and Tangerås 2008; Aspachs-Bracons et al. 2008; Fidrmuc, Ginsburgh, and Weber 2009; Ginsburgh and Weber 2010). It is also related to the education literature in as much as it examines the issue of bilingualism as well as the issues of languages of instruction and testing in schools (e.g., Ovando 2003; Parker, Rubalcava, and Teruel 2005, Menken 2008; Wiley, Lee, and Rumberger 2009). The paper also adds to the political science, economics, and education literature studying the turbulent post-Soviet region (e.g., Smith et al. 1998; Hughes 2005; Leping and Toomet 2008).

The rest of the paper is organized as follows. Section 2 provides the necessary background by discussing the ethnic and linguistic composition of Ukraine's population as well as by reviewing the main trends in the country's language policy since the 1991 independence, including the language policy change analyzed. In Section 3 we describe the methodology of the study. Section 4 discusses the data. Section 5 presents our empirical results. Section 6 concludes.

\section{Main ethnic groups, languages, and recent changes in the language policy in Ukraine}

\subsection{Ukraine’s ethnic and linguistic diversity}

With territory larger than Metropolitan France, and population over 45 million people, Ukraine is characterized by considerable ethnic diversity. According to the 2001 census, there were 10 ethnic groups with populations exceeding 100 thousand people in the country. Importantly, almost all population is native; only a tiny fraction of it consists of immigrants 
who came to Ukraine after its independence in 1991. Ukrainians are by far the largest ethnic group, constituting $77.8 \%$ of the population (see Table 1). Russians are the second largest ethnic group amounting to $17.3 \%$ of the population. The other large minorities include Byelorussians, Moldovans, Crimean Tatars, Bulgarians, Hungarians, Romanians, Poles, and Jews. Many ethnic groups are localized in border areas, e.g., most Hungarians and Romanians live close to the borders with the respective countries, but many are spread across Ukraine. For example, Byelorussians are spread quite uniformly across the regions while Russians, although particularly concentrated in the East and Crimea, are represented in large numbers in all regions. ${ }^{2}$

The country has considerable linguistic diversity. A heritage of the Russian Empire and USSR is a disproportional use of Russian by ethnic Ukrainians and other ethnic minorities. This is directly related to the explicit and implicit Russification which occurred over most of the $19^{\text {th }}$ and $20^{\text {th }}$ centuries and which is well documented in the literature (see, e.g., Pavlenko 2008). ${ }^{3}$ For example, at the time of gaining independence, only $49.3 \%$ of all schoolchildren studied in schools with Ukrainian as the language of instruction while Russian was used in $50.0 \%$ of all schools in Ukraine (Stepanenko 2003). To a large extent, this reflected parents' choices of the language of instruction for their children rather than unavailability of Ukrainian schools. Indeed, as noted by Bilaniuk (2005, p.38), in the USSR, Ukrainian language and culture were associated with "the rural sphere, ... provincialism, lower education, unculturedness, and weakness," while Russian was associated with “centrality, better and higher education, high culture, and strength.” Although Ukrainian was taught as compulsory subject in Russian schools as well as schools with other minority languages, it was often neglected by schoolchildren and their parents because of its perceived lower status.

Table 2 provides recent data about self-declared ethnicities and native languages in Ukraine. The data suggest that a considerable fraction of ethnic Ukrainians declare Russian as their mother tongue. This tendency is even more pronounced among other ethnic groups, especially Greeks, Jews, and Byelorussians. Table 3 shows an even more remarkable picture. Here, the data are based on 22,462 individual interviews held in Ukraine in 2003 in which respondents were able to choose between Ukrainian and Russian as the language of the interview. Among ethnic Ukrainians, only half revealed their preference for interview in

\footnotetext{
${ }^{2}$ Source: http://www.ukrcensus.gov.ua/eng/ as of December 1, 2010.

${ }^{3}$ Bilinsky (1981, p.320) provides a curious example from the late USSR period: Ukrainian schoolchildren in Ukraine were taught Russian from a textbook titled "The Native Language", while they studied Ukrainian, their true native language, from textbooks called “The Ukrainian Language”.
} 
Ukrainian, 17.9\% were indifferent between Ukrainian and Russian and 32.0\% preferred Russian. Strong preference for Russian is also documented among other ethnic groups. Based on such evidence, Kulyk (2010 p. 85) suggests that "Ukraine can be considered a rather atypical country, at least for Europe, in view of a discrepancy between linguistic and ethnic identities of the population and between each of these identities and patterns of everyday language use."4

\subsection{Language policy since independence}

The Ukrainian constitution defines Ukrainian as the only state language and declares support for minority languages, including Russian. ${ }^{5}$ Promotion of Ukrainian in government institutions, education, science, and culture has been, however, the main component of the state language policy since independence in 1991. It was regarded as an essential element of nation-state building. ${ }^{6}$ Indeed, from 1991 to 1995, the early period of Ukraine’s independence and presidency of Leonid Kravchuk (in office 1991-1994), the government pursued a policy of "speedy Ukrainization”, which was later admitted as a mistake. ${ }^{7}$ It was followed by a gradualist approach (under President Leonid Kuchma, in office 1994-2005) aimed at “evolutionary transformation in favor of the Ukrainian language” (Stepanenko 2003). ${ }^{8}$

The first decade of the promotion of Ukrainian brought visible results, such as dramatic changes in the linguistic landscape of cities (Pavlenko 2010) and a substantial increase in the share of schools with Ukrainian language of instruction (Stepanenko 2003). ${ }^{9}$

\footnotetext{
${ }^{4}$ See also Arel (2002) and Barrington and Faranda (2009).

${ }^{5}$ Article 10 of the constitution reads: "The State language of Ukraine shall be the Ukrainian language. The State shall ensure comprehensive development and functioning of the Ukrainian language in all spheres of social life throughout the entire territory of Ukraine. Free development, use, and protection of Russian and other languages of national minorities of Ukraine shall be guaranteed in Ukraine. The State shall promote the learning of languages of international communication. The use of languages in Ukraine shall be guaranteed by the Constitution of Ukraine and shall be determined by law.”

${ }^{6}$ D’Anieri (2002, p.5) provides a good illustration of these ideas: “The Ukrainian national identity ... should be defined in terms of Ukrainian ethnicity and language... To the liberal argument in favor of toleration of ethnic and linguistic pluralism (and hence, acceptance of the Russian language, perhaps, even as an official language), two responses are made. First is the argument ... that a single identity is required for the state to thrive, and that construction of such an identity is a historical norm. Second is an argument concerning historical justice: For the Ukrainian state to now adopt a liberal policy that freezes in place the results of past Russification efforts is to reward past oppression and to ensure its success. On the contrary, it is argued, historical justice requires that the oppression be reversed".

${ }^{7}$ According to Anatoliy Pohribnyi, $1^{\text {st }}$ deputy minister of education in the early 1990 s, "Education in Ukraine is to be fully and unconditionally subordinated to the building up of an independent Ukrainian state". Cited from Kuzio (1998, p.62).

${ }^{8}$ Kuchma's position is reflected in his address to the parliament on February 22, 2000 where he stated that "one should not talk too much about ... [the issues of language and religion], avoiding political turbulence around that, but practically work on resolving them”. Quoted from Stepanenko (2003, p. 122).

${ }^{9}$ According to Pavlenko (2009), in Kyiv, a largely Russian-speaking city, only 6 Russian-language schools remain out of 129 that existed in 1991. This does not even follow the ethnic makeup of the population, as according to the 2001 census, Russians constitute $13.1 \%$ of the city's population.
} 
However, as noted by Stepanenko (2003) and also suggested by the data in Table 3, the shaky balance between the two main languages largely remained intact.

The presidency of Victor Yushchenko, who succeeded Leonid Kuchma following the 2004 Orange Revolution, saw a dramatic shift in the language policy in favor of rather aggressive Ukrainization. The radical decisions taken by the new government included the requirement to conduct broadcasting in Ukrainian only (Kulyk 2010), the ban for cinemas to show movies in foreign languages (including Russian) without dubbing into Ukrainian or providing Ukrainian subtitles (Pavlenko 2008) ${ }^{10}$, and tougher language policies in schools. In the latter case, the government, for example, attempted to obligate school teachers to constantly use Ukrainian outside the classroom in all publicly funded educational establishments. ${ }^{11}$ The official policy between 2005 and 2009 was that the Ukrainian language was in danger and needed to be defended.

The Ukrainization policies, whether soft or more aggressive, faced considerable opposition on the part of most ethnic Russians and also some russophone Ukrainians and were accompanied by extensive debates the country (see, e.g., Fournier 2002; Seals 2009). Not surprisingly, language policy has been one of the key political issues in Ukraine and an essential element of all electoral campaigns, both presidential and parliamentary, since the 1991 independence. A key issue has been whether Russian should be given the status of a second state language, some other official status in the whole country or, at least, some status in the predominantly Russian-speaking regions. ${ }^{12}$ The promise to give the Russian language an official status was one of the slogans of both presidential campaigns of Victor Yanukovich (President of Ukraine since 2010). All in all, the language issue is one of the key components of the many divides observed in modern Ukraine with linguistic variables appearing among important determinants of socio-economic outcomes in empirical studies (see, e.g., Constant, Kahanec, and Zimmermann 2006a, 2006b; Brück et al. 2010). Interestingly, the debate about

\footnotetext{
${ }^{10}$ As Pavlenko (2008, p.275) describes it, “In December of 2007, the Constitutional Court of Ukraine announced that starting in 2008 all foreign-language movies shown in the country will have to be translated into Ukrainian via dubbing, subtitles, or synchronous translation. There would be nothing attention-worthy about this announcement if the 'foreign language' category didn't also include Russian, the native language of $30 \%$ of the population of Ukraine (www.ukrcensus.gov.ua), and one used and understood by the majority of the remaining $70 \%$. The new law thus was not driven by linguistic needs, as it would be in the case of movies in French, Danish or Hindi. Nor was it driven by economic needs - the demand for Russian-language books and media continues to be high in Ukraine, and the measure may actually be detrimental to the already struggling film industry. In fact, it is the popularity of the Russian-language media - inconsistent with Ukraine's nationalizing agenda and political aspirations and alliances - that drives the new law whose purpose is to ensure that Ukrainian citizens live in a Ukrainian-language environment.”

11 Resolution of the Cabinet of Ministers of Ukraine N. 1033 of September 5, 2009, revoked by the Constitutional Court on February 2, 2010.

12 Although Ukraine ratified the European Charter of Minority Languages, its provisions have not been implemented due to the lack of supporting regulations.
} 
languages is so much overshadowed by the Ukrainian-Russian divide, that only a tiny fraction of the population is concerned about other minority languages in the country, as surveys suggest (Kulyk 2008).

\subsection{Language policy in education}

The contemporary educational system of Ukraine consists of four levels: preschool, school (embracing primary and secondary education), higher, and postgraduate education. Since recently, secondary education (involving 11 years of schooling) is compulsory for all pupils. The bulk of all schools in Ukraine are public schools that are government funded. Private secondary education plays a very limited role in the country. All schools are classified into several types: regular schools, advanced learning schools (e.g., lyceums, gymnasiums, and specialized schools), special schools (usually for disabled children), as well as boarding schools (usually for orphans). Importantly, there are linguistic minority schools/classes funded by the state in eight languages: Bulgarian, Crimean Tatar, Hungarian, Moldovan, Polish, Romanian, Russian, and Slovak. ${ }^{13}$ In these schools, all or most subjects are taught in one of the minority languages while Ukrainian is a compulsory subject and is taught from the beginning of the study. Detailed statistics on the language of instruction in Ukrainian schools in the 2008/9 academic year is shown in Table 4.

Access to higher education in Ukraine is via a nationwide standardized test called “External Independent Testing”, the EIT, gradually introduced since 2004, and fully operative since 2008. Participation in the EIT is voluntary, and required only of those who intend to acquire higher education (the test plays a role of an entry exam to universities and colleges). In 2009 and 2010, the EIT included eight subjects and students were allowed to take up to five of them. ${ }^{14}$ The registration for the EIT usually starts in December and ends in March, and the exams take place from the beginning of May to the beginning of June. ${ }^{15}$ The test in Ukrainian language and literature is compulsory; either Math or History of Ukraine is compulsory, too. ${ }^{16}$ All tests (except for the test in Ukrainian language and literature) can be taken in six minority languages. When registering for the EIT, students can request translated tests in Crimean Tatar, Hungarian, Moldovan, Polish, Romanian, and Russian. No translation

\footnotetext{
${ }^{13}$ This is largely a heritage from the USSR: Ukraine had a considerable number of schools with instruction in minority languages (other than Russian) before its independence in 1991.

${ }^{14}$ The subjects are: Ukrainian language and literature, History of Ukraine, Math, Physics, Chemistry, Biology, Geography, and Foreign Language. Students taking the test in Foreign Language may choose between English, French, German, and Spanish, which effectively increases the number of subjects to 11 .

${ }^{15}$ The opening and closing dates for registration for the 2009(2010) EIT were 1(15) December 2008 (2009) and 1(15) March 2009 (2010).

${ }^{16}$ A second compulsory subject (Math or History) is a feature of the 2010 EIT. In the 2009 EIT, Ukrainian language and literature was the only compulsory subject.
} 
into Bulgarian and Slovak is provided due to the small number of pupils in schools with these languages of instruction.

The practice of providing translated tests to minority students was challenged after the appointment of Yulia Timoshenko's $2^{\text {nd }}$ government (in power between December 18, 2007 and March 04, 2010). In particular, on December 25, 2007, one week after the government had assumed office, the minister of education and science issued Order No. 1171 stating that, from 2008 on, all final tests would have to be taken in Ukrainian, while pupils from minority schools would be allowed to use a basic Ukrainian-mother tongue dictionary, if it was requested during the registration for the EIT. As the decision caused protests across the country, a month later, on January 24, 2008, the minister issued Order No. 33, which established a two-year transitory period between 2008 and 2009, during which translated tests would still be provided to minority students. The end of the transitory period in 2010 was reconfirmed in Order No. 570 of June 26, 2009.

Timoshenko's second government fell after the victory of Victor Yanukovich in the 2010 presidential elections. A new government, headed by Yanukovich’s ally Nikolay Azarov, was appointed on March 11, 2010. A few weeks after the appointment of the new government, on March 25, 2010, the new minister of education issued Order No. 238 stating that the EIT could again be taken in six minority languages. Thus, Timoshenko's government language policy was reversed. Importantly, it was reversed in the very last moment, 10 days after the closing date for the 2010 EIT registration and just a few weeks before the test. ${ }^{17}$

\subsection{Hypotheses}

Even though the change in the language policy was reversed in the very last moment, it may nevertheless have affected minority students in a number of ways. This is because preparation for testing takes time and students make high-stake decisions about their participation in the EIT, as well as about test subjects, well in advance. In particular, we expect that the (reversed) reform may have affected:

- test participation rates among minority students (some of them may decide not to take part in the EIT and thus not to pursue further studies at the university level),

- quantity of subjects chosen (minority students may decide to concentrate on a smaller number of subjects, which would restrict their choice of future fields of study in colleges and universities),

\footnotetext{
${ }^{17}$ According to Order No. 238, all students who requested a mother tongue-Ukrainian dictionary during the registration for the 2010 EIT, would be allowed to use translated tests. Additionally, all students were given the right to request a change in language of the EIT until April 8, 2010.
} 
- mix of subjects chosen by minority students (in particular, they may switch to subjects with milder requirements in terms of fluency in Ukrainian),

- scores in the Ukrainian language and literature test (an improvement may be expected as a result of greater investments of minority students in learning Ukrainian),

- scores obtained in other subjects (here, an unambiguous prediction is difficult to formulate: on the one hand, if minority students focus on a smaller number of subjects, they may prepare better for the EIT, on the other hand, the mix of subjects chosen may be sub-optimal, leading to a lower performance in the EIT).

\section{Methodology}

\subsection{The difference-in-difference regression analysis}

Our empirical strategy rests on a key assumption that the (announced but not implemented) policy change should have affected minority schools and not Ukrainian ones. Also, we use the fact that essential conditions of the EIT (such as the number and list of subjects) did not change between 2009 and 2010. ${ }^{18}$ These particular features allow us to use the difference-indifference (DID) estimator for evaluating the effect of the 2010 language policy change, which was intended to impose Ukrainian as the only language for the EIT. ${ }^{19}$ Specifically, we consider changes in the performance of minority schools (treatment group) between 2009 and 2010 relative to changes in performance of Ukrainian schools (control group) during the same period. In the most general form with two time periods, one pre- and one post-treatment, the regression equation can be written in the following way:

$$
Y_{i t}=\beta_{0}+\beta_{1}\left(G_{i} T_{t}\right)+\beta_{2} G_{i}+\beta_{3} T_{t}+\boldsymbol{X}_{i t} \boldsymbol{\gamma}+\varepsilon_{i t,}
$$

where $Y_{i t}$ is an outcome variable, such as the performance of schools in the EIT, variable $G_{i}$ is a treatment group dummy which equals 1 if a school was affected by the experiment (policy change) and 0 otherwise, $T_{t}$ is a time dummy that equals 1 in the post-treatment period, $G_{i} T_{t}$ is the interaction of the treatment group dummy and the time dummy, $\boldsymbol{X}_{i t}$ is a vector of additional control variables, and $\varepsilon_{i t}$ is a random disturbance. Subscripts $i$ and $t$ index schools and time respectively, with $t$ taking two values, 0 and 1 , for the pre- and post-treatment

\footnotetext{
18 The list of subjects in the 2008 EIT was different. It included, for example, History of the World, Fundamentals of Economics, and Fundamentals of Law, but excluded Foreign Language. In comparison with the 2009 and 2010 tests, the 2011 test would include Russian language in the list of optional subjects (interestingly, Russian will not be placed in the category Foreign Language).

${ }^{19}$ The DID estimator is a commonly used empirical estimation technique in program evaluation studies. It estimates the causal effect of an experiment (such as a policy change) as the average change in the outcome in the treatment group minus the average change in the control group over the course of the experiment. An important virtue of the DID estimator is that it remains consistent even if treatment is correlated with the initial level of outcome before the experiment.
} 
periods, respectively. The parameter of interest is $\beta_{1}$, which captures the average change in the outcome due to the treatment.

The dependent variable, $Y_{i t}$, differs from specification to specification depending on the hypothesis being tested. It may measure, for example, the overall participation in the test, take-up and failure rates, or tests scores on specific subjects. The treatment group dummy, $G_{i}$, takes the value of 1 if the language of instruction in the school is different from Ukrainian. The inclusion in the econometric model of vector $\boldsymbol{X}_{i t}$ can be justified by efficiency reasons if the respective variables measure factors that account for a part of the variation in the performance of schools not attributable to the treatment itself. Vector $X_{i t}$ may include, for example, characteristics of school location as well as school type.

As some of the important characteristics of schools may be unobserved, we consider an extended model which includes school fixed effects:

$$
Y_{i t}=\beta_{0}+\beta_{1}\left(G_{i} T_{t}\right)+\beta_{2} G_{i}+\beta_{3} T_{t}+\boldsymbol{X}_{i t} \boldsymbol{\gamma}+u_{i}+\varepsilon_{i t},
$$

where $u_{i}$ denotes time-invariant unobserved characteristics of school $i$ (school $i$ fixed effect). By controlling for such unobserved characteristics of schools, we ensure consistency of regression estimates. Note that all time-invariant characteristics of schools in specification (2) are subsumed in the school fixed effects $u_{\boldsymbol{i}}$. The coefficients on the respective time-invariant variables cannot therefore be estimated.

Whenever we deal with grouped data, such as the average score in a particular subject attained by students from a particular school, we employ analytic weights in the regression analysis. This adjusts for differences in the number of observations giving raise to the relevant average. In the above example with the average score in a particular subject, the weights would be based on the number of students from each school taking exam in that subject. Finally, our inference is based on cluster robust standard errors with clustering on schools.

\subsection{Defining the treatment and control groups}

In estimating the effect of the change in the language policy on minority students we focus on linguistic minorities other than Russians or russophone Ukrainians. We believe that such an approach makes the natural experiment that we exploit in this study much more pure and cleaner for at least two reasons. First, Russian and Ukrainian are closely related and are easily mixed, giving rise to the so-called “surzhik” (see, e.g., Bernsand 2001, Bilaniuk 2004). In particular, as summarized in Bilaniuk and Melnyk (2008, p.70), "Ukrainian and Russian are both East Slavic languages, and share many grammatical and lexical features (see Bilaniuk, 2005: 2003-2008 for a brief comparison). In lexicon, Ukrainian and Russian differ by 38\%; 
the $62 \%$ of the lexicon that these languages have in common consists of $44 \%$ morphemically identical and 18\% morphemically similar terms (Radchuk, 2002, citing research by Tyshchenko, 2000: 266-267). In comparison, Spanish and Portuguese differ by 25\%, Spanish and Italian by 33\%, and German and Dutch by 25\% (ibid)." Second, our concern is the ongoing shift from Russian to Ukrainian as the language of instruction in schools. It is very difficult, if not impossible, to follow this shift year-by-year and reliably separate Russian schools from Ukrainian schools. In addition, many schools are mixed and have parallel classes in both languages.

After abandoning the idea of comparing the performance of Ukrainian schools with the performance of Russian ones, we have closely examined the results of the 2009 and 2010 EIT in order to identify a suitable treatment group for our study. It turns out that the only three other languages that are frequently used in the EIT are Hungarian, Moldovan, and Romanian (see Table 5 which shows the languages of the Math test chosen by students in both 2009 and 2010). ${ }^{20}$ Importantly, Table 5 suggests localization of students requesting the EIT in Hungarian, Moldovan, and Romanian in three regions, namely, Chernivtsi, Odesa (Budjak part), and Zakarpattia oblasts of Ukraine. ${ }^{21}$ The location of these regions on the map of Ukraine is shown on Figure $1 .^{22}$

We therefore select schools with Hungarian, Moldovan, and Romanian languages of instruction for our treatment group. This perfectly fits the purpose of our study for at least two reasons. First, these languages are unrelated or loosely related to Ukrainian as they are from different branches and even families (Hungarian belongs to the Uralic family of languages rather than to the Indo-European one; Romanian is an Indo-European language from the Romance branch, which is loosely related to the Slavic branch, to which Ukrainian belongs). Second, the localization of minority schools in the three regions makes them relatively easy to identify.

In choosing a proper control group, we have two considerations. First, we want to minimize effects of potential confounding factors, such as economic development (which may

\footnotetext{
${ }^{20}$ The latter two languages are closely related; in fact, Moldovan is often regarded as a dialect of Romanian. The constitution of Moldova, however, says that the state language in the country is the Moldovan language (Article 13).

${ }^{21}$ These territories were acquired by Ukraine in 1939-1940. Their current (Census 2001) ethnic composition is as follows. In Chernivtsi oblast (0.922 mln people), Ukrainians constitute $75.0 \%$, Romanians $12.5 \%$, Moldovans 7.3\%, and Russians $4.1 \%$ of the population. In Odesa oblast (Budjak part, 0.617 mln people) Ukrainians amount to $40.2 \%$, Bulgarians to $20.9 \%$, Russians to $20.2 \%$, Moldovans to $12.7 \%$, and Gagauz to $4.0 \%$. In Zakarpattia oblast (1.258 mln people), the share of Ukrainians is $80.5 \%, 12.1 \%$ of the population are Hungarians, $2.6 \%$ are Romanians, and $2.5 \%$ are Russians.

${ }^{22}$ Minority schools are quite localized within these three regions. For example, ethnic Hungarians constitute over $25 \%$ of population in only four out of 17 districts of Zakarpattia oblast, namely, the town of Berehovo, as well as in Berehovsky, Vinohradivsky, and Uzhgorodsky districts.
} 
affect the financing of schools) and shares of urban versus rural population in the regions. Second, we want to make sure that our control group is comprised of Ukrainian schools located in predominantly Ukrainian-speaking areas and not, for example, in a predominantly Russian-speaking environment. Having examined the region- and district-level data, we have selected two distinct control groups for our study. Control group 1 consists of Ukrainian schools in Zakarpattia and Chernivtsi oblast. We exclude Ukrainian schools from Odesa oblast as it is predominantly Russian-speaking with a great mix of various nationalities and thus does not represent a proper control group. Control group 2 consists of Ukrainian schools in Ternopil oblast. This region is close to the three treatment group regions both geographically and economically. Importantly, it is very homogenous in terms of the ethnic and linguistic composition. Ukrainians constitute $97.8 \%$ of the population and the Ukrainian language is native for $98.3 \%$ of the residents. This is also evidenced in Table 5: only eight out of 4,641 students taking part in the 2009 EIT in Ternopil oblast asked for translated tests.

\section{Data}

We have access to the official results of the 2009 and 2010 EIT by regions, districts, schools, and subjects published by the Ministry of education and science of Ukraine. The test results are available at http://www.vintest.org.ua/statistics.aspx (the link is valid as of October 1, 2010). These data contain information on the name and location, as well as type of each school (e.g., ordinary secondary, gymnasium, lyceum, etc.), number of students taking tests in each of the eight subjects offered, and distribution of grades obtained by students in each subject by 10 categories. Because the test in Ukrainian language and literature is compulsory, the number of pupils taking this particular test is equal to the total number of pupils participating in the EIT.

As to the results of each test, the data are aggregated into 10 categories, from 100 (the lowest test score) to 200 (the highest test score). Specifically, the first category embraces scores from 100 to 123.5 and is officially regarded as a failure on the test, the second category ranges from 124 to 135.5, and the third one from 136 to 150. Category nine embraces scores in the range from 195.5 to 199.5 , and category 10 corresponds to $100 \%$ correct answers on the test questions (test score equal to 200). Knowing the distribution of students across these categories, we can approximate the average score for each school and each subject. We do so by taking the mid-points of each of the first nine intervals and 200 for the top category. Thus, we assume the score of 111.75 for category 1 and 129.75 for category 2, 197.5 for category 9, and 200 for category 10. 
Overall, the available data allow us to construct the following dependent variables for the difference-in-difference regression analysis: the number of students taking part in the final exam (Number of pupils), the average number of subjects chosen by students (No. subjects per pupil), the average score and failure rate in the (compulsory) Ukrainian language and literature test (Score_Ukrainian and Failed_Ukrainian, respectively), the percentage of students taking the test in a particular subject (Takeup_Subject) ${ }^{23}$, the share of failed tests in each subject (Failed_Subject), and the average score in each subject (Score_Subject). ${ }^{24}$

For the reasons discussed in Section 3.2, we restrict our analysis to schools in four regions: Chernivtsi, Odesa, Ternopil, and Zakarpattia oblasts. The data available to us contain no information about the size of schools, number of teachers, and size of graduate cohorts. More importantly, there is usually no info about the language of instruction, although some schools incorporate this information in their names (e.g., "Secondary school with Hungarian language of instruction named after Ferentz Rakotsi, village Vari, Berehovo district, Zakarpattia oblast”). We therefore looked for information on the web-sites of regional governments and municipal authorities, searched in local newspapers and news agencies, and also checked available studies of ethnic minorities in Ukraine. During this extensive search we identified over 100 secondary schools with either Hungarian, Romanian/Moldovan as well as Russian languages of instruction in the selected regions of Ukraine. We then eliminated few Russian and Russian-Ukrainian schools from the sample. This left us with 96 Hungarian and Romanian/Moldovan secondary schools, which we allocated to the treatment group. ${ }^{25}$ Ukrainian secondary schools form the control group in our study. We believe that given the data available, our classification is accurate and complete, although some minor mistakes cannot, of course, be ruled out. ${ }^{26}$

As to control variables, we create three dummies for the size of settlements in which schools are located (variable Village, base category, for small settlements with less than 30 thousand inhabitants, variable Town for settlements with 30-100 thousand inhabitants, and variable City for larger towns) and six dummies for school types (Regular school, base

\footnotetext{
${ }^{23}$ This is computed as the number of students taking the test in, say, Biology, divided by the number of students taking the test in Ukrainian language and literature (which, as explained above, is the total number of students participating in the EIT).

${ }^{24}$ Apart from the compulsory test in Ukrainian language and literature, in both 2009 and 2010, students could take tests in History of Ukraine, Math, Physics, Chemistry, Biology, Geography, and Foreign Language (English, French, German, or Spanish).

${ }^{25}$ The difference between this number and the number of schools with Hungarian and Romanian/Moldovan languages of instructions in Table 4 is due to the fact that many schools counted in Table 4 are primary or middle-level schools, which do not provide complete secondary education.

${ }^{26}$ We have also consulted the register of schools in Ukraine. Unfortunately, it provides no information about the language of instruction. It turns out that the relevant data can only be collected from regional and municipal authorities, upon authorization in the Ministry of education and science in Kyiv.
} 
category, standing for regular schools, Gymnasium, Lyceum, Specialized school, Special school, and Boarding school for the other school types). We hypothesize that the quality of schools may be higher in larger settlements. There may also be strong effects of school types, with gymnasiums, lyceums and specialized schools performing better in comparison with regular schools, and particularly in comparison with special schools and boarding schools. Note that because all these variables are time-invariant, they drop in the specifications with school fixed effects.

Descriptive statistics of the 2009 data are shown in Table 6. As anticipated, schools from the treatment and control groups are similar in many dimensions. Nevertheless, there is some between-group variation. In particular, the average number of students taking part in the EIT is considerably larger in Ukrainian schools as compared with minority schools, which probably reflects a smaller size of minority schools (as already mentioned, we have no information about school size). This interpretation is perfectly consistent with the fact that very few (only 3\%) Hungarian and Romanian schools are located in cities with populations above 100,000. There are also more lyceums in the treatment group as compared with the control group. Traditionally, lyceums provide better education services, but in the case of minority schools the name "lyceum" may simply indicate an advanced study of the minority language. Table 6 also suggests some differences in the performance of schools from the treatment and control groups, measured as (a) the percentage of pupils who failed a particular exam and (b) the average test score. As one might expect, the share of students who failed the test in Ukrainian language and literature is substantially higher in minority schools as compared with Ukrainian ones. The raw difference amounts to 25\%. The data in Table 6 also show that schools in the control group have lower failure rates in the Biology and Chemistry exams, but the differences are considerably smaller (5-7\%) in magnitude than in the case of Ukrainian language and literature.

\section{Empirical results}

As discussed in Section 3, we use two different control groups to identify the effect of the language policy change on minority students. One includes Ukrainian schools from Chernivtsi and Zakarpattia oblasts and the other one consists of schools in ethnically homogenous Ternopil oblast. We therefore have two sets of empirical results and present them sequentially.

\subsection{Ukrainian schools in Chernivtsi and Zakarpattia oblasts as the control group}


Columns 1-2 of Table 7 show the difference-in-difference estimates of changes in the participation rate in the EIT, with and without controlling for school fixed effects. The dependent variable is the number of students from each school participating in the EIT. Variable Minority is a dummy indicating minority language schools and captures the difference between the treatment and control group at the baseline. Variable Year2010 is a dummy for the year 2010 and captures the time effect. Variable Minority*Year2010 represents the interaction of variable Minority with variable Year2010, and is the main variable of interest indicating the treatment effect.

Both regressions, with and without school fixed effects, show a similar picture. The number of pupils taking exams drops in 2010 as compared with 2009, but there is no statistically significant difference between Ukrainian and minority schools. The coefficient on the interaction of the treatment and time dummies is positive (contrary to our expectations) but fails to achieve statistical significance at the conventional levels. Among the other results, we see that the number of pupils participating in the EIT is larger in cities and towns as compared with smaller settlements (although it should be acknowledged that the result may simply indicate larger classes in schools located in urban areas) ${ }^{27}$, and also larger in gymnasiums and lyceums (this is likely to be related to better educational standards in these types of schools, rather than to larger classes). There is also a significant baseline difference between Ukrainian and minority schools in terms of the number of pupils, as suggested by the coefficient on variable Minority. Again, this may reflect the smaller size of minority schools, many of which are located in rural areas.

In Columns 3-4 of Table 7 we report the results of estimating the effect of the language policy change on the average number of subjects chosen by students in minority schools. Regardless of whether we use school fixed effects or not, the regression results show a sizeable and statistically significant reduction in the number of subjects chosen by students from minority language schools as opposed to students from Ukrainian schools. The magnitude of the coefficient suggests that a group of ten minority students would, on average, take two exams less compared with a group of ten Ukrainian students. As the average number of exams (including the compulsory exam in Ukrainian) is equal to 2.4, the effect implies a $9 \%$ reduction in the take-up rate. The estimates also indicate no statistically significant difference at the baseline between Ukrainian and minority schools in terms of the average number of subject chosen by pupils. The large and statistically significant coefficient on variable Year2010 (the time trend) reflects the shift from one to two compulsory exams

\footnotetext{
${ }^{27}$ Again, we have no data on either the size of schools or number of graduating students.
} 
between 2009 and 2010 (only Ukrainian in 2009 versus Ukrainian plus either History or Math in 2010).

Table 8 shows the results concerning the effect of the policy change on the performance of minority students in the Ukrainian language and literature test. Here we consider two (closely related) dependent variables - the percentage of pupils failing the test in Ukrainian language and literature, variable Failed_Ukrainian, (first two columns in Table 8) and the average score in that test, variable Score_Ukrainian, for each school (last two columns in the table). As before, we show the results obtained with and without controlling for school fixed effects.

First of all, we observe a large discrepancy between Ukrainian and minority schools at the baseline. The average score on the Ukrainian language and literature test is substantially smaller in minority schools compared with Ukrainian schools. Similarly, the failure rate is substantially larger among minority schools. Specifically, after controlling for a number of characteristics of schools and weighting the data by the number of pupils participating in the testing, the failure rates differ by nearly 21\%. Note that the data in Table 6 show the unconditional and unweighted difference in the failure rates of $25 \%$ in 2009 : while only $12 \%$ of pupils fail the test in Ukrainian schools, over 37\% fail it in minority schools.

When we evaluate the effect of the policy change on the failure rates among minority students, our data suggest no statistically significant results. The coefficients on variable Minority*Year2010 are negative (which would suggest some improvement in the fluency in Ukrainian among minority students), but insignificant even at the $10 \%$ level. The coefficients in the regressions with the average score as the dependent variable are positive (which would suggest an improvement among minority students), but only the first of the two coefficients, namely, the one obtained without controlling for school fixed effects, is statistically significant at the $10 \%$ level. ${ }^{28}$ Overall, this analysis provides little evidence of improvements in the Ukrainian language and literature test results for minority students. Although they knew in advance that a good command of Ukrainian would be a key to successful testing, they seem to have not achieved any notable improvement in their language skills. The huge baseline difference between Ukrainian and minority schools is remarkable and alarming, especially if

\footnotetext{
${ }^{28}$ A caveat is due. In the case of the Ukrainian language and literature test, the observed improvement in the minority students' test scores is not necessarily fully attributable to the language policy change analyzed. The estimated coefficient may partially reflect a general trend towards better proficiency in Ukrainian among minority students, which seems quite plausible given the Ukrainization efforts since 1991. In technical terms, the parallel trend assumption that underlies the difference-in-difference estimator may not hold in this specific case. Unfortunately, the lack of data prevents us from a more careful assessment of this issue.
} 
it is driven by inadequate quality of teaching in minority schools, of which there is some, albeit fragmented, evidence (e.g., Bilaniuk and Melnyk 2008).

Table 9 shows the results for the take-up of specific subjects. The dependent variables are the percentages of students (among those participating in the test, that is, among those taking the Ukrainian language and literature test) choosing a particular subject. The results in Panel A are obtained using OLS without controlling for school fixed effects, the corresponding results with school fixed effects are shown in Panel B. The estimates in Panel A indicate a drop in the take-up rates for History, Biology, and Geography among minority students. For these subjects, the coefficients on the interaction of the treatment and time dummies, Minority*Year2010, are negative and statistically significant. We also see positive, albeit statistically insignificant, coefficients for the regressions with Math and Chemistry take-up rates as the dependent variable. Overall, the results suggest that minority students, when deciding which subjects to take at the $2010 \mathrm{EIT}$, had a preference for subjects that were less demanding in terms of the knowledge of Ukrainian (compare Math with Biology, for example). The results in Panel B of Table 9, which are obtained controlling for school fixed effects, are similar qualitatively, albeit there is only one coefficient which is statistically significant - in the regression with Geography take-up rates as the dependent variable.

Table 10 shows the results for the percentage of failed tests in each subject as the dependent variable. Panel A reports the results obtained without controlling for school fixed effects, and Panel B shows the estimates obtained with school fixed effects included in the regressions. As one might expect, there are no systematic differences at the baseline between Ukrainian and minority students (see Panel A). In only two cases we observe statistically significant coefficients (differently signed) on variable Minority, namely, in the regressions with Biology and German as the dependent variables. The results in Panel B of Table 10 do not suggest any statistically significant effect of the language policy change on the performance of minority students either. The estimates obtained using school fixed effects show a statistically significant increase in the failure rates on the foreign language tests (English in particular) among minority students. However, this result is only significant at the $10 \%$ level.

The results in Table 11 show the effect of the treatment on the average scores in each subject, rather than on the failure rates, and thus compliment the above findings. Interestingly enough, now there is a sizeable difference at the baseline between Ukrainian and minority schools in four out of 10 regressions. In particular, the average scores on the tests in History, Physics, Chemistry, and Biology turn out to be lower in minority schools as compared with 
Ukrainian schools. The fact that minority students fail roughly the same percentage of tests as Ukrainian students (Table 10), but their average scores are nevertheless lower (Table 11), is interesting. It may, in principle, indicate substantial differences in the quality of teaching between Ukrainian and minority schools. However, due to insufficient data, we leave this issue for further research. As regards the effect of the language policy change per se, the OLS regressions in Table 11 only suggest a statistically significant (at the $10 \%$ level) decline in the average score on the German language test. ${ }^{29}$ When school fixed effects are introduced in the regressions, this effect disappears and no other coefficients on the main variable of interest, Minority*Year2010, appear statistically significant. Thus, there is little evidence of any sizeable effect of the change in the language policy on the test scores.

To sum up, our analysis thus far suggests a drop in the number of subjects chosen by minority students as well as a shift to subjects that are less demanding in terms of the knowledge of Ukrainian (e.g., Math as opposed to Biology). We see no statistically significant effects of the language policy change on the test scores obtained by minority students.

\subsection{Schools in Ternopil oblast as the control group}

Next, we repeat the same analysis using a different control group. Now, instead of schools with Ukrainian language of instruction from Chernivtsi and Zakarpattia oblasts, we use Ukrainian schools from Ternopol oblast as the control group. The descriptive statistics for the new control group are shown in Table 12. In presenting and discussing the new results, we follow exactly the same steps as before. To avoid repetitions, we omit most details and focus on the most important findings only.

In particular, similarly to the earlier results we see no change in the EIT participation rate among minority students (Columns 1-2 of Table 13). Interestingly enough, both the difference at the baseline in terms of the participation rate (variable Minority) and the time trend (variable Year2010) reported in Table 13 are very similar to those shown in Table 7, where a different control group was used. As before, we see a negative effect of the change in the language policy on the average number of subjects taken by minority students (Columns 3-4 of Table 13). The effect is somewhat larger (by about one third) as compared with our previous estimates in the corresponding columns of Table 7. Now, a group of ten minority students would take three exams less compared with a group of ten Ukrainian students. The new results shown in Table 13 are also similar to those reported in Table 7 in terms of the time effects and difference at the baseline between the treatment and control groups.

\footnotetext{
${ }^{29}$ It should be noted that the corresponding regression is based on a rather small number of observations. In both 2009 and 2010, the German language test was chosen by students in less than 100 schools.
} 
Table 14 displays several particularly interesting results. We see an improvement in the minority students' scores in the Ukrainian language and literature test between 2009 and 2010. The result is statistically significant in three out of four specifications. Qualitatively, the failure rate dropped by about $3 \%$ and the average score rose by about 3.6 points or $2.7 \% .^{30}$ This is in contrast to our earlier findings where no statistically significant changes in the performance on the Ukrainian language and literature test were detected. Note that the difference at the baseline between Ukrainian and minority schools is substantially larger in Table 14 as compared with Table 8 . We believe this can be explained by the remarkable ethnic and linguistic homogeneity of the population of Ternopol oblast, where non-Ukrainians are virtually absent. How large is the improvement in the fluency in Ukrainian among minority students? The estimates suggest that between 2009 and 2010, about 15\% of the initial gap (the calculation relates the coefficient on variable Minority*Year2010 to the coefficient on variable Minority) was closed.

Table 15 shows the results for the take-up rates of particular subjects. Overall, the OLS results (Panel A) are in line with the previous findings. We see a particularly strong reduction in the take-up of exams in History, Biology, and Geography. Note also a negative effect on the take-up of Math, although it is smaller and less significant than the effects on the three subjects mentioned above. When we include school fixed effects, we still see strong negative effects of the change in the language policy on the take-up of exams in History and Geography by minority students. The respective coefficients are significant at the $1 \%$ and $5 \%$ levels. There is also an increase in the take-up of exams in foreign languages (taken together) among minority students. ${ }^{31}$ These results are in line with the idea that the announcement of the language policy change stimulated minority students to refocus on subjects with milder requirements for fluency in Ukrainian. And this is in line with our previous findings for the different control group. Note, however, that the results for Math and Physics in Panel B of Table 15 are not fully in line with this interpretation as they suggest a decline in the take-up of both subjects by minority students. These results are, however, significant at the $10 \%$ level only.

The most remarkable results of the regressions reported in Tables 16 and 17, which focus on the failure rates and average scores, are large differences at the baseline between

\footnotetext{
${ }^{30}$ Again, this improvement is not necessarily fully attributable to the policy change analyzed.

${ }^{31}$ When interpreting this result, it is useful to recall the overall decline in the number of subjects chosen by minority students. On the background of such a decline, the shift of minority students' preferences towards foreign languages is even more apparent.
} 
Ukrainian and minority schools. ${ }^{32}$ The OLS results in Panel A of Table 16 suggest no effect of the policy change on the failure rate in minority schools in any of the subjects. The fixedeffects results in Panel B of Table 16 confirm this finding. The analysis of the average score tests is more interesting (Table 17). Here again, we see a substantial baseline difference between Ukrainian and minority schools (Panel A), the largest in Chemistry and History. However, in contrast to the results for the failure rates, there are now significant effects of the policy change on the performance of minority students. In particular, the average scores on the Math and Chemistry tests seem to have improved in minority schools. The result survives the inclusion of school fixed effects as the results in Panel B show.

Overall, the results in this section are similar to the results reported in Section 5.1 in terms of the effect of the policy change on both the number of subjects taken by minority students and shifts in the take-up of particular subjects. The results in this section also provide evidence that minority students improved their fluency in Ukrainian between 2009 and 2010 (the results in Section 5.1 provided only weak evidence of that). Finally, the estimates presented in this section suggest some effects of the policy change on tests scores, which, however, seem to have no straightforward interpretation.

\section{Conclusions}

In this paper we take advantage of a recent natural experiment in Ukraine's secondary education system to study the effect of stricter requirements for proficiency in the state language on the education of linguistic minority students. Although one typically expects improvements in minority students' proficiency in the dominant language as a result of such policies, there may be important side effects, for example, due to the sorting of minority students into less linguistically demanding fields of study. As a result, state language policies may induce distortions in the accumulation of human capital by minority groups.

The reform that we consider was planned for the 2009/2010 academic year and obligated all minority students, including those studying in public schools with a full cycle of education in minority languages, to take a standardized school exit test (which is also a university entry test) in Ukrainian, the state language, thus denying them previously granted access to translated tests. Our empirical analysis is based on school-level data from the 2009 and 2010 standardized school exit tests and employs a difference-in-difference framework in which schools with Hungarian, Moldovan, and Romanian languages of instructions are placed

\footnotetext{
${ }^{32}$ Again, we have no data to assess whether this result may be related to factors such as the lack of qualified teachers or textbooks in minority languages in minority schools. In any case, our finding is an early warning for Ukrainian policy-makers.
} 
in the treatment group and schools with Ukrainian language of instruction constitute the control group.

The main results of our study are as follows. We find fairly strong evidence that the change in the language policy has resulted in a decline in the number of subjects taken by minority students at the school exit test. There is also a notable shift in the take-up of particular subjects, with fewer exams taken by minority students in more linguisticallydemanding subjects such as History, Biology, and Geography, and more exams taken in foreign languages and Math. This has immediate consequences for access of minority students to further education at the university level as entry to different universities and different fields of study require tests in different subjects. We also find some evidence that minority students improved their proficiency in Ukrainian between 2009 and 2010 (which was probably the main goal of the policy change). Overall, our results suggest important distortions in the accumulation of human capital by linguistic minority students induced by the language policy change that imposed stricter requirements for proficiency in the state language.

We believe that our study provides a fine contribution to the small but rapidly growing literature at the intersection of economics, education, and linguistics. We also believe that our analysis have important policy implications. In particular, policy-makers advocating aggressive promotion of the state language among linguistic minority groups (which, ceteris paribus, improves socio-economic outcomes of these groups and is therefore beneficial for society and the economy) should also consider potential negative effects, at least in the shortrun, associated with the reaction of linguistic minorities on such policies. Distortions in the accumulation of human capital by minority groups, which we document in our study, are a case in point. 


\section{References}

Arel, Dominique (2002) Interpreting "Nationality" and "Language" in the 2001 Ukrainian Census. Post-Soviet Affairs, 18(3): 213-249.

Aspachs-Bracons, Oriol, Irma Clots-Figueras, Joan Costa-Font, and Paolo Masella (2008) Compulsory Language Educational Policies and Identity Formation, Journal of the European Economic Association, 6(2-3): 434-444.

Barrington, Lowell and Regina Faranda (2009) Reexamining Region, Ethnicity, and Language in Ukraine. Post-Soviet Affairs, 25(3): 232-256.

Bernsand, Niklas (2001) Surzhyk and National Identity in Ukrainian Nationalist Language Ideology. Berliner Osteuropa Info, 17: 38-47.

Bilaniuk, Laada (2004) A Typology of Surzhyk: Mixed Ukrainian-Russian Language. International Journal of Bilingualism, 8(4): 409-425.

Bilaniuk, Laada (2005) Contested Tongues: Language Politics and Cultural Correction in Ukraine. Ithaca, NY: Cornell University Press.

Bilaniuk, Laada and Svitlana Melnyk (2008) A Tense and Shifting Balance: Bilingualism and Education in Ukraine. International Journal of Bilingual Education and Bilingualism, 11(34): 340-72.

Bilinsky, Yaroslav (1981) Expanding the Use of Russian or Russification? Some Critical Thoughts on Russian As a Lingua Franca and the "Language of Friendship and Cooperation of the Peoples of the USSR”. Russian Review, 40(3): 317-332.

Bleakley, Hoyt and Aimee Chin (2004) Language Skills and Earnings: Evidence from Childhood Immigrants, Review of Economics and Statistics, 86(2): 481-496.

Brück, Tilman, Alexander M. Danzer, Alexander Muravyev, and Natalia Weisshaar (2010) Poverty during Transition: Household Survey Evidence from Ukraine. Journal of Comparative Economics, 38(2): 123-145.

Chiswick, B. R. (1991) Speaking, Reading, and Earnings among Low-skilled Immigrants', Journal of Labor Economics, 9(2): 149-70.

Chiswick, Barry R. and Paul W. Müller (2007) The Economic Cost to Native-born Americans of Limited English Language Proficiency. In: Barry R. Chiswick and Paul W. Müller "The Economics of Language: International Analyses,” New York: Routledge.

Constant, Amelie, Martin Kahanec, and Klaus F. Zimmermann (2006a) The RussianUkrainian Earnings Divide. IZA Discussion Paper No. 2330, Institute for the Study of Labor.

Constant, Amelie, Martin Kahanec, and Klaus F. Zimmermann (2006b) The RussianUkrainian Political Divide. IZA Discussion Paper No. 2530, Institute for the Study of Labor.

D’Anieri, Paul (2002) Introduction: Debating the Assumptions of State-Led Nation Building in Ukraine. In: Taras Kuzio and Paul D’Anieri, “Dilemmas of State-led Nation-state Building in Ukraine”, Praeger Publishers, Westport, CT. Paul.

Dustmann, Christian and Francesca Fabbri (2003) Language Proficiency and Labour Market Performance of Immigrants in the UK, Economic Journal, 113(489): 695-717.

Fidrmuc, Jan and Victor Ginsburgh (2007), Languages in the European Union: The Quest for Equality and Its Cost, European Economic Review 51, 1351-1369.

Fidrmuc, Jan, Victor Ginsburgh, and Shlomo Weber (2009) Voting on the Choice of Core Languages in the European Union, European Journal of Political Economy, 25(1): 56-62. 
Fournier, Anna (2002) Mapping Identities: Russian Resistance to Linguistic Ukrainianisation in Central and Eastern Ukraine, Europe, Asia Studies, 54(3): 41533.

Fry, Richard and B. Lindsay Lowell (2003) The Value of Bilingualism in the U.S. Labor Market. Industrial and Labor Relations Review, 57(1): 128-141.

Gazzola, Michele (2006) Managing Multilingualism in the European Union: Language Policy Evaluation for the European Parliament. Language Policy, 5(4): 393-417.

Ginsburgh, Victor, and Shlomo Weber (2010) The Economics of Linguistic Diversity - How Many Languages Make Sense? Princeton: Princeton University Press.

Ginsburgh, Victor, Ignacio Ortuno-Ortin, and Shlomo Weber (2005) Disenfranchisement in Linguistically Diverse Societies. The Case of the European Union. Journal of the European Economic Association, 3(4): 946-964.

Grin, François (2003) Language Planning and Economics. Current Issues in Language Planning, 4(1): 1-66.

Grin, Francois (2006) Economic Considerations in Language Policy. In: Ricento, Thomas (Ed.) An Introduction in Language Policy. Maiden/Oxford: Blackwell.

Grin, François and François Vaillancourt (1999) The Cost-effectiveness Evaluation of Minority Language Policies: Case Studies on Wales, Ireland and the Basque Country. Monograph series, No. 2. Flensburg: European Centre for Minority Issues.

Henley, Andrew and Rhian Eleri Jones (2005) Earnings And Linguistic Proficiency In A Bilingual Economy, Manchester School, 73(3): 300-320.

Hughes, James (2005) 'Exit' in Deeply Divided Societies: Regimes of Discrimination in Estonia and Latvia and the Potential for Russophone Migration. Journal of Common Market Studies, 43(4): 739-762.

Hutchinson, William K. (2005) "Linguistic Distance” as a Determinant of Bilateral Trade, Southern Economic Journal, 72(1): 1-15.

Jacob, James E. and David C. Gordon (1985) Language Policy in France. In: Beer, William R. and James E. Jacob (Eds.) Language Policy and National Unity. Totowa, New Jersey: Rowman \& Allanheld Publishers.

Khmelko, Valery (2004) Ethno-linguistic structure of Ukraine: Regional features and tendencies of changes during independence. Unpublished manuscript, Kyiv Institute for Sociology. Retrieved on November 1, 2010 from http://www.kiis.com.ua/txt/pdf/ing-ethn.pdf

Krishna, Aradhna and Rohini Ahluwalia (2008) Language Choice in Advertising to Bilinguals: Asymmetric Effects for Multinationals versus Local Firms. Journal of Consumer Research, 35(4): 692-705.

Kulyk, Volodymyr (2008) Language Policy in Ukraine: What People Want the State to Do? Paper presented at the Sciences Po-ASN conference on "Empires and Nations", Paris, 3-5 July 2008.

Kulyk, Volodymyr (2010) Ideologies of Language Use in Post-Soviet Ukrainian Media. International Journal of the Sociology of Language, 201(1): 79 - 104

Kuzio, Taras (1998) Ukraine: State and Nation Building. London: Routledge.

Leping, Kristian-Olari and Toomet, Ott (2008) Emerging Ethnic Wage Gap: Estonia during Political and Economic Transition. Journal of Comparative Economics, 36(4): 599-619. 
MacMillan, Michael (2003) Federal Language Policy in Canada and the Quebec Challenge. In: Pierre Larrivee (Ed.) Linguistic Conflict and Language Laws: Understanding the Quebec Question. New York: Palgrave MacMillan.

Marschak, Jacob (1965) Economics of Language. Behavioral Science, 10(2): 135-140.

Marschan-Piekkaria, Rebecca, Dennis Welch, and Lawrence Welch (1999) In the Shadow: The Impact of Language on Structure, Power and Communication in the Multinational. International Business Review 8(4): 421-440.

McManus, Walter, William Gould, and Finis Welch (1983) Earnings of Hispanic Men: The Role of English Language Proficiency. Journal of Labor Economics, 1(2): 101-30.

Melitz, Jacques (2008) Language and Foreign Trade. European Economic Review, 52(4): 667-699.

Menken, Kate (2008) English Learners Left Behind: Standardized Testing as Language Policy. Clevedon: Multilingual Matters.

Ministry of Education and Science of Ukraine (2009) On the Results of Development of School, Pre-school and Out-of-school Education in the 2008/2009 Academic Year and Goals for the 2009/2010 Academic Year. Information-analytical materials of the Debriefing Board of the Ministry of Education and Science of Ukraine, August 26, 2009 Retrieved on November 1, 2010 from http://www.mon.gov.ua/newstmp/2009_1/19_08/inf.doc (in Ukrainian).

Ortega, Javier and Thomas P. Tangerås (2008) Unilingual versus Bilingual Education: A Political Economy Analysis. Journal of the European Economic Association, 6(5): 10781108.

Ovando, Carlos J. (2003) Bilingual Education in the United States: Historical Development and Current Issues. Bilingual Research Journal, 27(1): 1-24.

Parker, Susan W., Rubalcava, Luis, and Teruel, Graciela (2005) Schooling Inequality and Language Barriers. Economic Development and Cultural Change, 54(1): 71-94.

Pavlenko, Aneta (2008) Multilingualism in Post-Soviet Countries: Language Revival, Language Removal, and Sociolinguistic Theory. International Journal of Bilingual Education and Bilingualism, 11(3-4): 275-314.

Pavlenko, Aneta (2009) The Status and Use of Russian in the Post-Soviet Space. Voprosy Fililogii, 32(2): 27-35.

Pavlenko, Aneta (2010) Linguistic Landscape of Kyiv, Ukraine: A Diachronic Study. In: Elana Shohamy, Eliezer Ben-Rafael, and Monica Barni (Eds.) Linguistic Landscape in the City, Multilingual Matters, Tonawanda, NY.

Puntoni, Stefano, Bart de Langhem, and Stijn M. J. van Osselaer (2009) Bilingualism and the Emotional Intensity of Advertising Language. Journal of Consumer Research, 35(6): 10121025.

Radchuk, Vitaliy (2002) Language in Ukraine: State, Functions, Perspectives. Language Studies (Movoznavstvo), 2-3: 39-45; www.radchuk.novamova.com.ua (in Ukrainian).

Seals, Corinne (2009) From Russification to Ukrainisation: A Survey of Language Politics in Ukraine. The Undergraduate Journal on Slavic and East/Central European Studies, UCLA, Volume 2, 2009, http://www.international.ucla.edu/languages/slavicjournal/. 
Smith, Graham, Vivien Law, Andrew Wilson, Annette Bohr, and Edward Allworth (1998) Nation Building in the Post Soviet Borderlands: The Politics of National Identity. Cambridge, UK: Cambridge University Press, 2000.

Spolsky, Bernard (2003) Reassessing Māori Regeneration. Language in Society, 32(4): 553578.

Spolsky, Bernard (2004) Language Policy. Cambridge University Press, Cambridge, UK.

Stepanenko, Viktor (2003) Identities and Language Politics in Ukraine: The Challenges of Nation-State Building. In: Farimah Daftary and Francois Grin (Eds.) Nation-Building, Ethnicity and Language Politics in Transition Countries. Open Society Institute, Budapest.

Tyshchenko, Kostyantin (2000) Metatheory of Language Studies. Kyiv: Osnovy (in Ukrainian).

Wickström, Bengt-Arne (2005) Can Bilingualism be Dynamically Stable? A Simple Model of Language Choice. Rationality and Society, 17(1): 81-115.

Wiley, Terrence J., Jin Sook Lee, and Russell W. Rumberger, R. (2009) The Education of Language Minority Immigrants in the United States. Multilingual Matters: Bristol, UK. 
Table 1. Main ethnic groups of Ukraine, self-identification, census data.

\begin{tabular}{lccc}
\hline \hline Self-declared ethnicity & Number, ths. in 2001 & Percent in 2001 & Percent in 1989 \\
\hline Ukrainians & $37,541.70$ & 77.8 & 72.7 \\
Russians & $8,334.10$ & 17.3 & 22.1 \\
Byelorussians & 275.8 & 0.6 & 0.9 \\
Moldovans & 258.6 & 0.5 & 0.6 \\
Crimean Tatars & 248.2 & 0.5 & 0.0 \\
Bulgarians & 204.6 & 0.4 & 0.5 \\
Hungarians & 156.6 & 0.3 & 0.4 \\
Romanians & 151 & 0.3 & 0.3 \\
Poles & 144.1 & 0.3 & 0.4 \\
Jews & 103.6 & 0.2 & 0.9 \\
Armenians & 99.9 & 0.2 & 0.1 \\
Greeks & 91.5 & 0.2 & 0.2 \\
Tatars & 73.3 & 0.2 & 0.2 \\
\hline \hline
\end{tabular}

Source: Census 1989, 2001.

Table 2. Self-declared ethnicity and native language, census data.

\begin{tabular}{lcccc}
\hline \hline \multirow{2}{*}{$\begin{array}{l}\text { Self-declared } \\
\text { ethnicity }\end{array}$} & \multicolumn{3}{c}{ Self-declared native language (2001) } \\
\cline { 2 - 5 } & $\begin{array}{c}\text { Language of own } \\
\text { nationality }\end{array}$ & Ukrainian & Russian & Other \\
\hline Ukrainians & 85.2 & - & 14.8 & 0.0 \\
Russians & 95.9 & 3.9 & - & 0.2 \\
Byelorussians & 19.8 & 17.5 & 62.5 & 0.2 \\
Moldovans & 70.0 & 10.7 & 17.6 & 1.7 \\
Crimean Tatars & 92.0 & 0.1 & 6.1 & 1.8 \\
Bulgarians & 64.2 & 5.0 & 30.3 & 0.5 \\
Hungarians & 95.4 & 3.4 & 1.0 & 0.2 \\
Romanians & 91.7 & 6.2 & 1.5 & 0.6 \\
Poles & 12.9 & 71.0 & 15.6 & 0.5 \\
Jews & 3.1 & 13.4 & 83.0 & 0.5 \\
Armenians & 50.4 & 5.8 & 43.2 & 0.6 \\
Greeks & 6.4 & 4.8 & 88.5 & 0.3 \\
Tatars & 35.2 & 4.5 & 58.7 & 1.6 \\
\hline \hline
\end{tabular}

Source: Census 2001. 
Table 3. Languages chosen at interviews, 2003.

\begin{tabular}{lcccc}
\hline \hline & \multicolumn{4}{c}{ Self-declared ethnicity } \\
\cline { 2 - 5 } Language chosen & Ukrainians & Russians & Other & All \\
\hline Ukrainian & 50.1 & 4.6 & 12.7 & 40.5 \\
Russian & 32.0 & 84.1 & 76.1 & 43.1 \\
Ukrainian and Russian (“does not matter”) & 17.9 & 11.2 & 11.2 & 16.4 \\
Total & 100 & 100 & 100 & 100 \\
\hline \hline
\end{tabular}

Note: Based on 22,462 individual interviews.

Source: Khmelko (2004).

Table 4. Schools with minority languages in Ukraine, 2008/9 school year.

\begin{tabular}{|c|c|c|c|c|c|c|}
\hline $\begin{array}{l}\text { Language/ } \\
\text { ethnic group }\end{array}$ & $\begin{array}{l}\text { Schools with } \\
\text { this language } \\
\text { of instruction } \\
\end{array}$ & $\begin{array}{l}\% \text { of all } \\
\text { schools }\end{array}$ & $\begin{array}{c}\text { Pupils in } \\
\text { schools with } \\
\text { this language }\end{array}$ & $\begin{array}{l}\% \text { of all } \\
\text { pupils }\end{array}$ & $\begin{array}{c}\text { Pupils studying } \\
\text { this lang. as } \\
\text { subject }\end{array}$ & $\begin{array}{c}\text { Pupils studying } \\
\text { this lang. as } \\
\text { elective } \\
\end{array}$ \\
\hline Bulgarian & - & & 80 & & 9,592 & 1275 \\
\hline Gagauz & - & & - & & 1,400 & - \\
\hline Hebrew and Yiddish & - & & - & & 1,292 & 114 \\
\hline Crimean Tatar & 15 & $0.1 \%$ & 484 & $0.0 \%$ & 17,725 & 5,153 \\
\hline Moldovan & 6 & $0.0 \%$ & 4,756 & $0.1 \%$ & 1,590 & 434 \\
\hline Russian & 1,199 & $6.0 \%$ & 779,423 & $17.6 \%$ & $1,292,518$ & 165,544 \\
\hline New Greek & - & & - & & 3,073 & 248 \\
\hline Polish & 5 & $0.0 \%$ & 1,389 & $0.0 \%$ & 6,889 & 4,443 \\
\hline Romanian & 89 & $0.4 \%$ & 21,671 & $0.5 \%$ & 683 & - \\
\hline Slovak & - & & 79 & $0.0 \%$ & 224 & 202 \\
\hline Hungarian & 66 & $0.3 \%$ & 16,407 & $0.4 \%$ & 1,337 & 278 \\
\hline
\end{tabular}

Note: 20,045 schools overall, 4,438,383 pupils in all schools.

Source: Ministry of education and science of Ukraine (2009). 
Table 5. Math test, 2009-2010, languages chosen.

Panel A: Math test 2009.

\begin{tabular}{|c|c|c|c|c|c|c|c|}
\hline Region & Ukrainian & Russian & " Hungarian & "Moldovan & Crim.Tatar & "Polish & " Romanian \\
\hline Crimea & 406 & 11,080 & & & 1 & & \\
\hline Vinnytsia & 9,154 & 98 & & & & & \\
\hline Volyn & 5,452 & 13 & & & & & \\
\hline Dnipropetrovsk & 17,477 & 6,762 & & & & & \\
\hline Donetsk & 4,455 & 20,585 & & & & & \\
\hline Zhytomyr & 7,770 & 150 & & & & & \\
\hline Zakarpattia & 4,395 & 77 & 267 & 1 & & & 14 \\
\hline Zaporizhia & 4,442 & 4,827 & & & & & \\
\hline Ivano-Frankivsk & 5,658 & 1 & & & & & \\
\hline Kyiv oblast & 9,906 & 231 & & & & & \\
\hline Kirovohrad & 5,442 & 323 & & & & & \\
\hline Luhansk & 2,527 & 10,657 & & & & & \\
\hline Lviv & 15,417 & 105 & & & & & \\
\hline Kyiv city & 14,584 & 817 & & & & 1 & \\
\hline Sebastopol & 28 & 2,013 & 1 & & & & \\
\hline Mykolaiv & 4,823 & 972 & & & & & \\
\hline Odesa & 7,561 & 6,256 & & 164 & & & 1 \\
\hline Poltava & 8,952 & 501 & & & & & \\
\hline Rivne & 7,334 & 6 & & & & & \\
\hline Sumy & 5,815 & 595 & & & & & \\
\hline Ternopil & 4,633 & 6 & & 2 & & & \\
\hline Kharkiv & 11,846 & 7,188 & & & & & \\
\hline Kherson & 4,554 & 1,427 & & & & & \\
\hline Khmelnytsky & 5,794 & 45 & & & & & \\
\hline Cherkasy & 6,086 & 122 & & & & & \\
\hline Chernivtsi & 2,702 & 22 & & 1 & & & 144 \\
\hline Chernihiv & 6,313 & 211 & & & & & \\
\hline Total & 183,526 & 75,090 & 268 & 168 & 1 & 1 & 159 \\
\hline
\end{tabular}

Panel B: Math test 2010.

\begin{tabular}{|c|c|c|c|c|c|c|c|}
\hline Region & Ukrainian & Russian & Hungarian & Moldovan & Crim.Tatar & Polish & Romanian \\
\hline Crimea & 511 & 11,580 & & & & & \\
\hline Vinnytsia & 8,941 & 142 & & & & & \\
\hline Volyn & 5,471 & 18 & & & & & \\
\hline Dnipropetrovsk & 16,908 & 7,354 & 4 & & & & \\
\hline Donetsk & 5,220 & 19,614 & & & & & \\
\hline Zhytomyr & 7,975 & 53 & & & & & \\
\hline Zakarpattia & 4,485 & 35 & 341 & & & & 34 \\
\hline Zaporizhia & 4,457 & 4,852 & & & & & 1 \\
\hline Ivano-Frankivsk & 6,179 & 14 & & & & & \\
\hline Kyiv oblast & 10,242 & 219 & & & & & \\
\hline Kirovohrad & 5,311 & 306 & & & & 1 & \\
\hline Luhansk & 2,490 & 10,518 & & & & & \\
\hline Lviv & 15,659 & 158 & & & & & \\
\hline Kyiv city & 14,593 & 897 & & & & & \\
\hline Sebastopol & 89 & 1,901 & & & & & \\
\hline Mykolaiv & 4,699 & 1,139 & 1 & & & & \\
\hline Odesa & 7,455 & 7,114 & & 139 & & & \\
\hline Poltava & 9,403 & 443 & & & & & \\
\hline Rivne & 7,233 & 0 & & & & & \\
\hline Sumy & 6,490 & 509 & & & & & \\
\hline Ternopil & 5,306 & 11 & & & & & \\
\hline Kharkiv & 11,472 & 8,355 & & & & & \\
\hline Kherson & 4,245 & 1,720 & & & & & \\
\hline Khmelnytsky & 6,341 & 21 & & & & & \\
\hline Cherkasy & 6,179 & 152 & & & & & \\
\hline Chernivtsi & 2,595 & 21 & & & & & 266 \\
\hline Chernihiv & 6310 & 201 & & & & & \\
\hline Total & 186259 & 77347 & 346 & 139 & 0 & 1 & 301 \\
\hline
\end{tabular}

Source: Official results of the EIT from the Ministry of education and science. 
Figure 1. Map of Ukraine with the regions selected for the study.

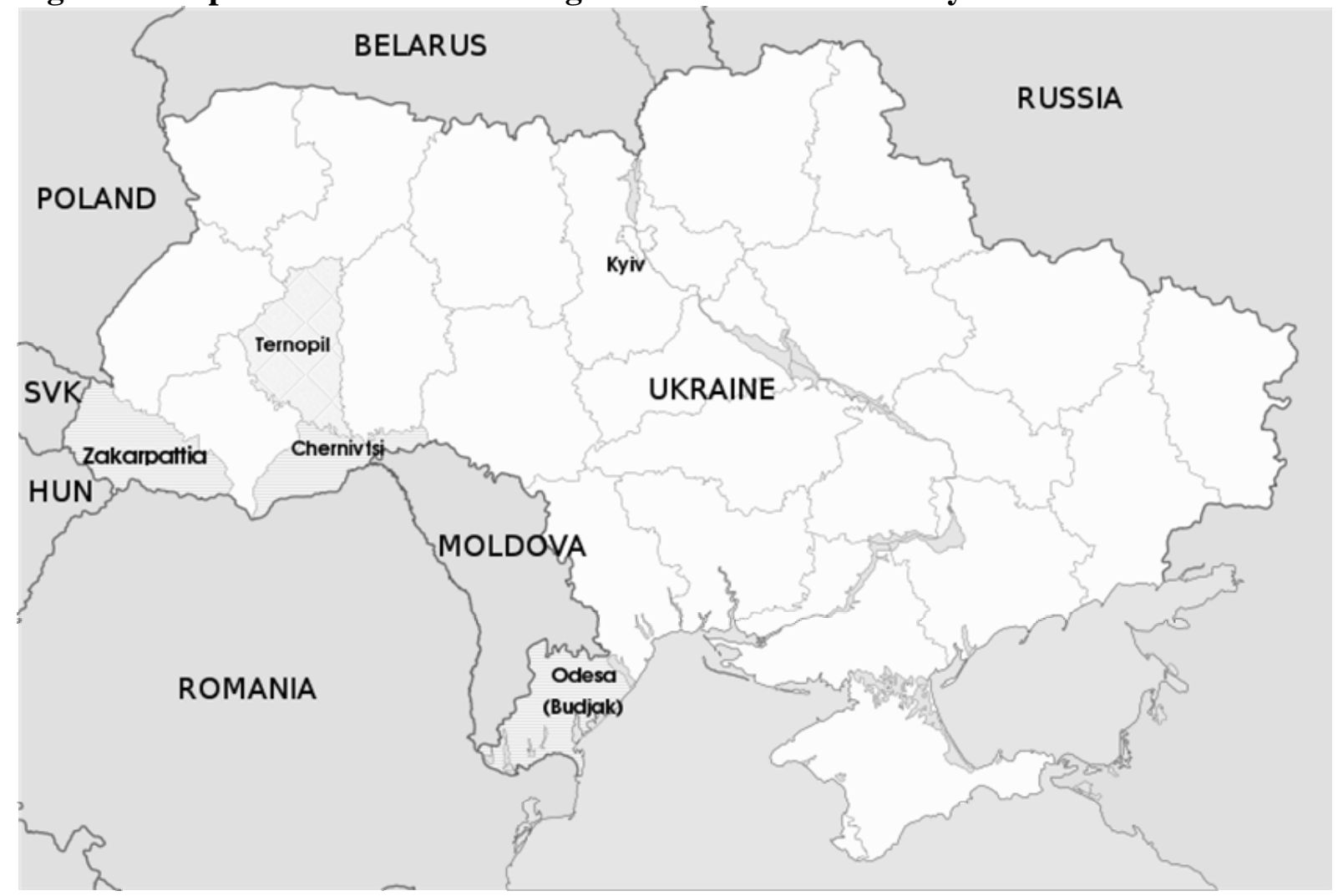

Source: The background map is taken from

http://upload.wikimedia.org/wikipedia/commons/thumb/9/93/Ukraine_location_map.svg/800pxUkraine_location_map.svg.png, the text and colour are added by the authors. 
Table 6. Descriptive statistics 2009, Ukrainian schools from Chernivtsi and Zakarpattia oblasts as the control group.

\begin{tabular}{|c|c|c|c|c|c|c|c|c|c|c|c|c|c|}
\hline & \multicolumn{6}{|c|}{ "Control group (Ukrainian schools) } & \multicolumn{6}{|c|}{ "Treatment group (Hungarian and Romanian schools) } & \multirow[t]{2}{*}{ Difference } \\
\hline & mean & St.d & $\min$ & median & $\max$ & $\mathrm{n}$ & mean & St.d & $\min$ & median & $\max$ & $\mathrm{n}$ & \\
\hline Number of pupils & 25.64 & 18.27 & 1 & 22.00 & 147 & 469 & 17.20 & 11.33 & 1 & 16.50 & 66 & 96 & $8.44 * * *$ \\
\hline No. subjects per pupil & 2.40 & 0.37 & 1.63 & 2.33 & 4.85 & 469 & 2.42 & 0.51 & 1.50 & 2.34 & 4.93 & 96 & -0.02 \\
\hline Town & 0.06 & 0.24 & 0 & 0 & 1 & 469 & 0.08 & 0.28 & 0 & 0 & 1 & 96 & -0.02 \\
\hline Gymnasium & 0.06 & 0.24 & 0 & 0 & 1 & 469 & 0.06 & 0.24 & 0 & 0 & 1 & 96 & 0.00 \\
\hline Lyceum & 0.03 & 0.16 & 0 & 0 & 1 & 469 & 0.08 & 0.28 & 0 & 0 & 1 & 96 & $-0.05 * * *$ \\
\hline Specialized & 0.01 & 0.10 & 0 & 0 & 1 & 469 & 0 & 0 & 0 & 0 & 0 & 96 & 0.01 \\
\hline Special & 0.01 & 0.08 & 0 & 0 & 1 & 469 & 0 & 0 & 0 & 0 & 0 & 96 & 0.01 \\
\hline Boarding school & 0.03 & 0.17 & 0 & 0 & 1 & 469 & 0.02 & 0.14 & 0 & 0 & 1 & 96 & 0.01 \\
\hline Takeup_Biology & 0.25 & 0.17 & 0 & 0.21 & 1 & 469 & 0.30 & 0.24 & 0 & 0.24 & 1 & 96 & $-0.05^{* *}$ \\
\hline Takeup_Physics & 0.06 & 0.08 & 0 & 0.03 & 0.54 & 469 & 0.08 & 0.11 & 0 & 0.04 & 0.56 & 96 & -0.02 \\
\hline Takeup_French & 0 & 0.03 & 0 & 0 & 0.54 & 469 & 0.03 & 0.12 & 0 & 0 & 1 & 96 & $-0.03 * * *$ \\
\hline Takeup_Geography & 0.17 & 0.17 & 0 & 0.13 & 1 & 469 & 0.12 & 0.17 & 0 & 0.07 & 1 & 96 & $0.05^{* * *}$ \\
\hline Takeup_Chemistry & 0.07 & 0.08 & 0 & 0.05 & 0.47 & 469 & 0.09 & 0.15 & 0 & 0.05 & 1 & 96 & $-0.02 * *$ \\
\hline Takeup_History & 0.38 & 0.2 & 0 & 0.36 & 1 & 469 & 0.34 & 0.23 & 0 & 0.33 & 1 & 96 & 0.04 \\
\hline Takeup_Math & 0.39 & 0.19 & 0 & 0.38 & 1 & 469 & 0.39 & 0.24 & 0 & 0.36 & 1 & 96 & 0.00 \\
\hline Takeup_German & 0.01 & 0.03 & 0 & 0 & 0.25 & 469 & 0.01 & 0.03 & 0 & 0 & 0.17 & 96 & 0.00 \\
\hline Takeup_Ukrainian & 1 & 0 & 1 & 1 & 1 & 469 & 1 & 0 & 1 & 1 & 1 & 96 & 0.00 \\
\hline Failed English & 0.12 & 0.26 & 0 & 0.00 & 1 & 251 & 0.09 & 0.16 & 0 & 0 & 0.50 & 33 & 3.12 \\
\hline Failed_Physics & 0.05 & 0.16 & 0 & 0.00 & 1 & 258 & 0.07 & 0.18 & 0 & 0 & 1 & 54 & -1.69 \\
\hline Failed_French & 0.09 & 0.29 & 0 & 0.00 & 1 & 23 & 0.03 & 0.12 & 0 & 0 & 0.50 & 19 & 5.63 \\
\hline Failed_Geography & 0.10 & 0.20 & 0 & 0.00 & 1 & 378 & 0.08 & 0.17 & 0 & 0 & 0.67 & 58 & 2.17 \\
\hline Failed_Chemistry & 0.09 & 0.23 & 0 & 0.00 & 1 & 300 & 0.15 & 0.28 & 0 & 0 & 1 & 55 & $-6.53 *$ \\
\hline Failed_History & 0.12 & 0.15 & 0 & 0.08 & 1 & 447 & 0.13 & 0.16 & 0 & 0.09 & 0.75 & 85 & -0.46 \\
\hline Failed_Math & 0.11 & 0.16 & 0 & 0.05 & 1 & 457 & 0.12 & 0.22 & 0 & 0 & 1 & 91 & -0.73 \\
\hline Failed_German & 0.03 & 0.14 & 0 & 0.00 & 1 & 87 & 0.00 & 0.00 & 0 & 0 & 0 & 8 & 3.20 \\
\hline Failed_Ukrainian & 0.12 & 0.11 & 0 & 0.10 & 0.58 & 469 & 0.37 & 0.24 & 0 & 0.35 & 1 & 96 & $-25.15^{* * *}$ \\
\hline Score English & 146.59 & 15.68 & 111.75 & 147.33 & 186.75 & 251 & 147.29 & 15.22 & 120.75 & 143.00 & 180.92 & 33 & -0.70 \\
\hline Score_Biology & 149.57 & 14.19 & 111.75 & 147.35 & 192.75 & 439 & 143.89 & 15.25 & 111.75 & 143.00 & 174.69 & 84 & $5.68 * * *$ \\
\hline Score_Physics & 153.66 & 16.44 & 111.75 & 152.50 & 197.50 & 258 & 146.93 & 15.69 & 111.75 & 143.00 & 182.38 & 54 & $6.73 * * *$ \\
\hline Score_French & 144.91 & 17.21 & 111.75 & 143.00 & 178.00 & 23 & 151.76 & 15.09 & 133.88 & 143.00 & 178.00 & 19 & -6.85 \\
\hline Score_Geography & 148.69 & 13.84 & 111.75 & 149.12 & 186.75 & 378 & 149.08 & 15.59 & 117.75 & 147.10 & 186.75 & 58 & -0.39 \\
\hline Score_Chemistry & 151.61 & 16.39 & 111.75 & 152.60 & 187.25 & 300 & 147.11 & 18.71 & 111.75 & 146.06 & 197.50 & 55 & $4.50 *$ \\
\hline Score_History & 148.05 & 11.41 & 111.75 & 146.89 & 182.38 & 447 & 143.81 & 11.69 & 116.25 & 142.90 & 186.75 & 85 & $4.24 * * *$ \\
\hline Score_Math & 149.09 & 12.61 & 111.75 & 148.95 & 179.95 & 457 & 146.85 & 13.53 & 111.75 & 145.95 & 192.75 & 91 & 2.24 \\
\hline Score_German & 154.86 & 22.00 & 111.75 & 148.50 & 200 & 87 & 155.44 & 20.22 & 129.75 & 155.00 & 189.00 & 8 & -0.58 \\
\hline Score_Ukrainian & 147.83 & 9.52 & 123.96 & 146.96 & 180.52 & 469 & 131.35 & 10.06 & 111.75 & 129.75 & 159.92 & 96 & $16.48^{* * *}$ \\
\hline
\end{tabular}

Asterisks denote significance levels: *** - significant at $1 \%$, ** - significant at $5 \%$ and ${ }^{*}$ - significant at $10 \%$. 
Table 7. The effect of the language policy change on participation in tests and average number of subjects chosen, OLS and FE estimates.

\begin{tabular}{|c|c|c|c|c|}
\hline & \multicolumn{2}{|c|}{$\begin{array}{c}\text { Dependent variable: Participation } \\
\text { in final tests }\end{array}$} & \multicolumn{2}{|c|}{$\begin{array}{c}\text { Dependent variable: } \\
\text { Average number of subjects chosen }\end{array}$} \\
\hline & OLS & $\mathrm{FE}$ & OLS & $\mathrm{FE}$ \\
\hline & (1) & (2) & (3) & (4) \\
\hline Minority*Year2010 & $\begin{array}{c}0.563 \\
(0.947)\end{array}$ & $\begin{array}{c}0.781 \\
(0.916)\end{array}$ & $\begin{array}{c}-0.222 * * * \\
(0.072)\end{array}$ & $\begin{array}{c}-0.206^{* * *} \\
(0.071)\end{array}$ \\
\hline Minority & $\begin{array}{c}-7.846 * * * \\
(1.501)\end{array}$ & & $\begin{array}{c}0.079 \\
(0.068)\end{array}$ & \\
\hline Year2010 & $\begin{array}{l}-3.965 * * * \\
(0.459)\end{array}$ & $\begin{array}{l}-4.076 * * * \\
(0.422)\end{array}$ & $\begin{array}{c}0.944^{* * *} \\
(0.020)\end{array}$ & $\begin{array}{c}0.934^{* * *} \\
(0.020)\end{array}$ \\
\hline Town & $\begin{array}{l}11.472 * * * \\
(3.251)\end{array}$ & & $\begin{array}{l}0.183^{* * *} \\
(0.040)\end{array}$ & \\
\hline City & $\begin{array}{l}13.705^{* * * *} \\
(2.965)\end{array}$ & & $\begin{array}{c}0.135 * * * \\
(0.034)\end{array}$ & \\
\hline Gymnasium & $\begin{array}{l}10.654 * * * \\
(3.004)\end{array}$ & & $\begin{array}{c}0.037 \\
(0.044)\end{array}$ & \\
\hline Lyceum & $\begin{array}{l}12.262 * * * \\
(4.415)\end{array}$ & & $\begin{array}{l}0.178 * * \\
(0.082)\end{array}$ & \\
\hline Specialized school & $\begin{array}{c}23.476 \\
(16.600)\end{array}$ & & $\begin{array}{c}0.176 \\
(0.133)\end{array}$ & \\
\hline Special school & $\begin{array}{l}-0.829 \\
(8.046)\end{array}$ & & $\begin{array}{c}-0.295 * * * \\
(0.096)\end{array}$ & \\
\hline Boarding school & $\begin{array}{l}-6.564 \\
(5.043)\end{array}$ & & $\begin{array}{l}0.192 * * \\
(0.096)\end{array}$ & \\
\hline Intercept & $\begin{array}{c}22.109 * * * \\
(0.747)\end{array}$ & $\begin{array}{c}24.472 * * * \\
(0.188)\end{array}$ & $\begin{array}{c}2.362 * * * \\
(0.017)\end{array}$ & $\begin{array}{c}2.437 * * * \\
(0.010)\end{array}$ \\
\hline $\begin{array}{l}\text { R-squared } \\
\text { No. obs. }\end{array}$ & $\begin{array}{c}0.23 \\
1,137\end{array}$ & $\begin{array}{c}0.17 \\
1,110\end{array}$ & $\begin{array}{c}0.65 \\
1,137\end{array}$ & $\begin{array}{c}0.82 \\
1,110\end{array}$ \\
\hline
\end{tabular}

The dependent variables indicate the number of students from each school participating in the EIT or the average number of subjects chosen by students in each school. Variable Minority is a dummy indicating minority language schools and captures the difference between the treatment and control group at the baseline. Variable Year2010 is a dummy for the year 2010 and captures the time trend. Variable Minority*Year2010 is the interaction of variable Minority with variable Year2010 and shows the treatment effect. Cluster-robust standard errors are reported in parentheses. Asterisks denote significance levels: *** - significant at $1 \%$, ** - significant at $5 \%$ and ${ }^{*}$ - significant at $10 \%$. 
Table 8. The effect of the language policy change on the failure rates and average scores in the Ukrainian language and literature exam, OLS and FE estimates.

\begin{tabular}{|c|c|c|c|c|}
\hline & \multicolumn{2}{|c|}{$\begin{array}{l}\text { Dependent variable: } \\
\text { Failed_Ukrainian }\end{array}$} & \multicolumn{2}{|c|}{$\begin{array}{l}\text { Dependent variable: } \\
\text { Score_Ukrainian }\end{array}$} \\
\hline & OLS & FE & OLS & FE \\
\hline & (1) & $(2)$ & (3) & (4) \\
\hline Minority*Year2010 & $\begin{array}{l}-2.475 \\
(2.023)\end{array}$ & $\begin{array}{l}-1.722 \\
(1.916)\end{array}$ & $\begin{array}{l}1.557^{*} \\
(0.945)\end{array}$ & $\begin{array}{c}1.376 \\
(0.869)\end{array}$ \\
\hline Minority & $\begin{array}{c}21.264 * * * \\
(2.025)\end{array}$ & & $\begin{array}{c}-14.725 * * * \\
(1.070)\end{array}$ & \\
\hline Year2010 & $\begin{array}{l}-0.321 \\
(0.511)\end{array}$ & $\begin{array}{l}-0.339 \\
(0.508)\end{array}$ & $\begin{array}{c}0.440 \\
(0.341)\end{array}$ & $\begin{array}{c}0.412 \\
(0.334)\end{array}$ \\
\hline Town & $\begin{array}{c}-4.511 * * * \\
(1.695)\end{array}$ & & $\begin{array}{c}6.409 * * * \\
(1.682)\end{array}$ & \\
\hline City & $\begin{array}{c}-5.894 * * * \\
(0.971)\end{array}$ & & $\begin{array}{c}9.377 * * * \\
(1.064)\end{array}$ & \\
\hline Gymnasium & $\begin{array}{c}-8.930 * * * \\
(1.149)\end{array}$ & & $\begin{array}{c}14.509 * * * \\
(1.454)\end{array}$ & \\
\hline Lyceum & $\begin{array}{l}-2.710 \\
(1.649)\end{array}$ & & $\begin{array}{c}3.225 \\
(2.283)\end{array}$ & \\
\hline Specialized school & $\begin{array}{l}-1.800 \\
(5.508)\end{array}$ & & $\begin{array}{c}2.261 \\
(4.852)\end{array}$ & \\
\hline Special school & $\begin{array}{c}-4.395^{* *} \\
(1.895)\end{array}$ & & $\begin{array}{c}5.864 * * * \\
(1.929)\end{array}$ & \\
\hline Boarding school & $\begin{array}{c}2.668 \\
(3.074)\end{array}$ & & $\begin{array}{l}-2.331 \\
(3.487)\end{array}$ & \\
\hline Intercept & $\begin{array}{c}13.831^{* * *} \\
(0.583)\end{array}$ & $\begin{array}{c}13.620 * * * \\
(0.249)\end{array}$ & $\begin{array}{l}145.428 * * * \\
(0.455)\end{array}$ & $\begin{array}{c}147.726^{* * * *} \\
(0.155)\end{array}$ \\
\hline $\begin{array}{l}\text { R-squared } \\
\text { No. obs. }\end{array}$ & $\begin{array}{c}0.36 \\
1,137 \\
\end{array}$ & $\begin{array}{c}0.01 \\
1,110 \\
\end{array}$ & $\begin{array}{c}0.52 \\
1,137 \\
\end{array}$ & $\begin{array}{c}0.01 \\
1,110 \\
\end{array}$ \\
\hline
\end{tabular}

The dependent variables indicate the percentage of students failing the test in Ukrainian language and literature (Failed_Ukrainian) and the average score in that test (Score_Ukrainian) for each school. Variable Minority is a dummy indicating minority language schools and captures the difference between the treatment and control group at the baseline. Variable Year2010 is a dummy for the year 2010 and captures the time trend. Variable Minority*Year2010 is the interaction of variable Minority with variable Year2010 and shows the treatment effect. Cluster-robust standard errors are reported in parentheses. Asterisks denote significance levels: *** - significant at 1\%, ** significant at $5 \%$ and * - significant at $10 \%$. 
Table 9. The effect of the language policy change on the take-up of particular subjects, OLS and FE estimates.

Panel A: OLS estimates.

\begin{tabular}{|c|c|c|c|c|c|c|c|c|c|c|}
\hline & "History & "Math & Physics & "Chemistry & "Biology & " Geography & English & French & German & "All languages \\
\hline Minority*Year2010 & $\begin{array}{c}-0.064 * * \\
(0.032)\end{array}$ & $\begin{array}{c}0.005 \\
(0.033)\end{array}$ & $\begin{array}{l}-0.009 \\
(0.039)\end{array}$ & $\begin{array}{c}0.031 \\
(0.061)\end{array}$ & $\begin{array}{c}-0.095^{* *} \\
(0.038)\end{array}$ & $\begin{array}{l}-0.086 * \\
(0.047)\end{array}$ & $\begin{array}{l}-0.019 \\
(0.051)\end{array}$ & $\begin{array}{l}-0.012 \\
(0.084)\end{array}$ & $\begin{array}{l}-0.087 \\
(0.063)\end{array}$ & $\begin{array}{l}-0.022 \\
(0.041)\end{array}$ \\
\hline Minority & $\begin{array}{c}0.001 \\
(0.030)\end{array}$ & $\begin{array}{c}0.017 \\
(0.030)\end{array}$ & $\begin{array}{c}0.055^{* *} \\
(0.028)\end{array}$ & $\begin{array}{l}0.048^{*} \\
(0.025)\end{array}$ & $\begin{array}{c}0.094 * * * \\
(0.030)\end{array}$ & $\begin{array}{c}0.016 \\
(0.046)\end{array}$ & $\begin{array}{c}0.087 \\
(0.055)\end{array}$ & $\begin{array}{c}0.079 \\
(0.077)\end{array}$ & $\begin{array}{c}0.022 \\
(0.023)\end{array}$ & $\begin{array}{l}0.084 * \\
(0.044)\end{array}$ \\
\hline Year2010 & $\begin{array}{c}0.368 * * * \\
(0.010)\end{array}$ & $\begin{array}{c}0.058^{* * *} \\
(0.010)\end{array}$ & $\begin{array}{c}0.034^{* * *} \\
(0.013)\end{array}$ & $\begin{array}{c}0.017^{* *} \\
(0.008)\end{array}$ & $\begin{array}{c}0.096 * * * \\
(0.012)\end{array}$ & $\begin{array}{c}0.223^{* * *} \\
(0.014)\end{array}$ & $\begin{array}{c}0.130 * * * \\
(0.017)\end{array}$ & $\begin{array}{c}0.004 \\
(0.045)\end{array}$ & $\begin{array}{c}0.090^{* * *} \\
(0.028)\end{array}$ & $\begin{array}{c}0.133^{* * *} \\
(0.015)\end{array}$ \\
\hline Town & $\begin{array}{l}-0.008 \\
(0.021)\end{array}$ & $\begin{array}{c}0.051 * * \\
(0.023)\end{array}$ & $\begin{array}{c}-0.055^{* * *} \\
(0.021)\end{array}$ & $\begin{array}{c}-0.046^{* * *} \\
(0.017)\end{array}$ & $\begin{array}{c}-0.146 * * * \\
(0.026)\end{array}$ & $\begin{array}{l}-0.032 \\
(0.031)\end{array}$ & $\begin{array}{c}0.096^{* *} \\
(0.042)\end{array}$ & $\begin{array}{l}-0.104 \\
(0.092)\end{array}$ & $\begin{array}{c}-0.045^{* *} \\
(0.021)\end{array}$ & $\begin{array}{c}0.129 * * * \\
(0.037)\end{array}$ \\
\hline City & $\begin{array}{l}-0.011 \\
(0.014)\end{array}$ & $\begin{array}{c}-0.041 \\
(0.025)\end{array}$ & $\begin{array}{l}-0.018 \\
(0.022)\end{array}$ & $\begin{array}{l}-0.034 \\
(0.023)\end{array}$ & $\begin{array}{c}-0.128 * * * \\
(0.025)\end{array}$ & $\begin{array}{c}0.047 * * \\
(0.022)\end{array}$ & $\begin{array}{c}0.124 * * * \\
(0.030)\end{array}$ & $\begin{array}{c}0.127 \\
(0.104)\end{array}$ & $\begin{array}{c}-0.017 \\
(0.037)\end{array}$ & $\begin{array}{c}0.134^{* * *} \\
(0.027)\end{array}$ \\
\hline Gymnasium & $\begin{array}{l}-0.037 * \\
(0.020)\end{array}$ & $\begin{array}{l}-0.013 \\
(0.029)\end{array}$ & $\begin{array}{l}-0.030^{*} \\
(0.017)\end{array}$ & $\begin{array}{l}-0.021^{*} \\
(0.012)\end{array}$ & $\begin{array}{c}-0.093 * * * \\
(0.025)\end{array}$ & $\begin{array}{c}-0.109 * * * \\
(0.026)\end{array}$ & $\begin{array}{c}0.254 * * * \\
(0.050)\end{array}$ & $\begin{array}{c}0.143 \\
(0.101)\end{array}$ & $\begin{array}{c}0.104 \\
(0.067)\end{array}$ & $\begin{array}{c}0.273^{* * *} * \\
(0.042)\end{array}$ \\
\hline Lyceum & $\begin{array}{c}0.005 \\
(0.035)\end{array}$ & $\begin{array}{c}0.089 \\
(0.067)\end{array}$ & $\begin{array}{l}0.105^{*} \\
(0.054)\end{array}$ & $\begin{array}{l}0.094 * \\
(0.053)\end{array}$ & $\begin{array}{c}0.030 \\
(0.083)\end{array}$ & $\begin{array}{l}-0.002 \\
(0.035)\end{array}$ & $\begin{array}{l}-0.007 \\
(0.030)\end{array}$ & $\begin{array}{l}-0.106 \\
(0.095)\end{array}$ & $\begin{array}{c}-0.038^{*} \\
(0.021)\end{array}$ & $\begin{array}{c}0.005 \\
(0.027)\end{array}$ \\
\hline Specialized school & $\begin{array}{l}-0.038 \\
(0.057)\end{array}$ & $\begin{array}{c}0.012 \\
(0.032)\end{array}$ & $\begin{array}{l}-0.048 \\
(0.036)\end{array}$ & $\begin{array}{l}0.048^{*} \\
(0.027)\end{array}$ & $\begin{array}{c}0.023 \\
(0.043)\end{array}$ & $\begin{array}{l}-0.059 \\
(0.044)\end{array}$ & $\begin{array}{c}0.140 \\
(0.092)\end{array}$ & & $\begin{array}{c}0.031 \\
(0.033)\end{array}$ & $\begin{array}{c}0.191^{* *} \\
(0.095)\end{array}$ \\
\hline Special school & $\begin{array}{c}-0.180 * * * \\
(0.031)\end{array}$ & $\begin{array}{c}-0.048 \\
(0.038)\end{array}$ & $\begin{array}{l}-0.017 \\
(0.021)\end{array}$ & $\begin{array}{c}0.028 \\
(0.034)\end{array}$ & $\begin{array}{l}-0.013 \\
(0.076)\end{array}$ & $\begin{array}{c}-0.209 * * * \\
(0.032)\end{array}$ & $\begin{array}{c}0.127 * * \\
(0.055)\end{array}$ & $\begin{array}{l}0.161 * \\
(0.085)\end{array}$ & & $\begin{array}{c}0.079 \\
(0.059)\end{array}$ \\
\hline Boarding school & $\begin{array}{c}0.050 \\
(0.037)\end{array}$ & $\begin{array}{c}0.020 \\
(0.036)\end{array}$ & $\begin{array}{c}0.102^{* * *} \\
(0.030)\end{array}$ & $\begin{array}{c}-0.078 * * * \\
(0.023)\end{array}$ & $\begin{array}{c}0.046 \\
(0.045)\end{array}$ & $\begin{array}{c}0.048 \\
(0.048)\end{array}$ & $\begin{array}{c}-0.165^{* * *} \\
(0.062)\end{array}$ & $\begin{array}{c}0.236 \\
(0.169)\end{array}$ & $\begin{array}{l}-0.051 \\
(0.035)\end{array}$ & $\begin{array}{c}-0.163 * * * \\
(0.060)\end{array}$ \\
\hline $\begin{array}{l}\text { R-squared } \\
\text { No. obs. }\end{array}$ & $\begin{array}{c}0.60 \\
1,101 \\
\end{array}$ & $\begin{array}{c}0.07 \\
1,096 \\
\end{array}$ & $\begin{array}{l}0.17 \\
648 \\
\end{array}$ & $\begin{array}{l}0.13 \\
681 \\
\end{array}$ & $\begin{array}{c}0.17 \\
1,059 \\
\end{array}$ & $\begin{array}{r}0.28 \\
944 \\
\end{array}$ & $\begin{array}{l}0.46 \\
607 \\
\end{array}$ & $\begin{array}{l}0.29 \\
105 \\
\end{array}$ & $\begin{array}{l}0.25 \\
179 \\
\end{array}$ & $\begin{array}{l}0.52 \\
745 \\
\end{array}$ \\
\hline \multicolumn{11}{|c|}{ Panel B: FE estimates. } \\
\hline & History & Math & Physics & Chemistry & Biology & " Geography & English & French & German & "All languages \\
\hline Minority*Year2010 & $\begin{array}{l}-0.049 \\
(0.030)\end{array}$ & $\begin{array}{c}0.008 \\
(0.032)\end{array}$ & $\begin{array}{c}-0.049 \\
(0.036)\end{array}$ & $\begin{array}{c}0.050 \\
(0.064)\end{array}$ & $\begin{array}{l}-0.059 \\
(0.036)\end{array}$ & $\begin{array}{c}-0.095^{* *} \\
(0.040)\end{array}$ & $\begin{array}{c}0.006 \\
(0.043)\end{array}$ & $\begin{array}{c}0.044 \\
(0.072)\end{array}$ & $\begin{array}{c}-0.051 \\
(0.054)\end{array}$ & $\begin{array}{c}0.012 \\
(0.034)\end{array}$ \\
\hline Year2010 & $\begin{array}{c}0.399 * * * \\
(0.010)\end{array}$ & $\begin{array}{c}0.062 * * * \\
(0.010)\end{array}$ & $\begin{array}{c}0.038 * * * \\
(0.012)\end{array}$ & $\begin{array}{c}0.007 \\
(0.008)\end{array}$ & $\begin{array}{c}0.100^{* * *} \\
(0.011)\end{array}$ & $\begin{array}{c}0.280^{* * * *} \\
(0.012)\end{array}$ & $\begin{array}{c}0.144^{* * *} \\
(0.016)\end{array}$ & $\begin{array}{l}-0.021 \\
(0.047)\end{array}$ & $\begin{array}{c}0.080^{* *} \\
(0.031)\end{array}$ & $\begin{array}{c}0.142^{* * *} \\
(0.014)\end{array}$ \\
\hline $\begin{array}{l}\text { R-squared } \\
\text { No. obs. }\end{array}$ & $\begin{array}{c}0.80 \\
1,044\end{array}$ & $\begin{array}{c}0.09 \\
1,044\end{array}$ & $\begin{array}{l}0.07 \\
454\end{array}$ & $\begin{array}{l}0.03 \\
484\end{array}$ & $\begin{array}{c}0.18 \\
990\end{array}$ & $\begin{array}{l}0.66 \\
820\end{array}$ & $\begin{array}{l}0.49 \\
472\end{array}$ & $\begin{array}{c}0.03 \\
60\end{array}$ & $\begin{array}{c}0.29 \\
98\end{array}$ & $\begin{array}{l}0.50 \\
570\end{array}$ \\
\hline
\end{tabular}

The dependent variables are the percentages of students (among those participating in the test = taking the Ukrainian language and literature test) taking a particular subject. Variable Minority is a dummy indicating minority language schools and captures the difference between the treatment and control group at the baseline. Variable Year2010 is a dummy for the year 2010 and captures the time trend. Variable Minority*Year2010 is the interaction of variable Minority with variable Year2010 and shows the treatment effect. Constant term is included in regressions, but not reported. Cluster-robust standard errors are reported in parentheses. Asterisks denote significance levels: *** significant at $1 \%$, ** - significant at $5 \%$ and $*$ - significant at $10 \%$. 
Table 10. The effect of the language policy change on the test failure rates, OLS and FE estimates.

\begin{tabular}{|c|c|c|c|c|c|c|c|c|c|c|}
\hline & " History & "Math & Physics & "Chemistry & Biology & " Geography & "English & French & German & All languages \\
\hline Minority*Year2010 & $\begin{array}{c}1.484 \\
(2.007)\end{array}$ & $\begin{array}{c}1.743 \\
(2.175)\end{array}$ & $\begin{array}{l}-3.067 \\
(2.550)\end{array}$ & $\begin{array}{l}-6.178 \\
(5.126)\end{array}$ & $\begin{array}{l}-1.580 \\
(2.831)\end{array}$ & $\begin{array}{c}2.199 \\
(3.580)\end{array}$ & $\begin{array}{c}1.764 \\
(2.952)\end{array}$ & $\begin{array}{l}-1.109 \\
(8.238)\end{array}$ & $\begin{array}{c}0.720 \\
(4.663)\end{array}$ & $\begin{array}{c}2.033 \\
(2.518)\end{array}$ \\
\hline Minority & $\begin{array}{c}1.003 \\
(1.932)\end{array}$ & $\begin{array}{l}-0.465 \\
(1.727)\end{array}$ & $\begin{array}{l}-0.780 \\
(1.980)\end{array}$ & $\begin{array}{c}5.534 \\
(3.411)\end{array}$ & $\begin{array}{c}5.167 * * \\
(2.459)\end{array}$ & $\begin{array}{l}-1.011 \\
(3.442)\end{array}$ & $\begin{array}{l}-1.649 \\
(2.597)\end{array}$ & $\begin{array}{l}-6.594 \\
(5.234)\end{array}$ & $\begin{array}{c}-6.279 * * \\
(2.679)\end{array}$ & $\begin{array}{l}-2.789 \\
(2.021)\end{array}$ \\
\hline Year2010 & $\begin{array}{c}-1.984 * * * \\
(0.627)\end{array}$ & $\begin{array}{c}-2.137 * * * \\
(0.681)\end{array}$ & $\begin{array}{c}1.022 \\
(1.338)\end{array}$ & $\begin{array}{c}3.734^{* *} \\
(1.766)\end{array}$ & $\begin{array}{l}-0.171 \\
(0.892)\end{array}$ & $\begin{array}{c}0.946 \\
(0.969)\end{array}$ & $\begin{array}{l}-0.845 \\
(1.048)\end{array}$ & $\begin{array}{c}6.483 \\
(5.458)\end{array}$ & $\begin{array}{l}5.327^{*} \\
(3.054)\end{array}$ & $\begin{array}{c}0.126 \\
(0.965)\end{array}$ \\
\hline Town & $\begin{array}{c}-3.855^{* * *} \\
(1.198)\end{array}$ & $\begin{array}{c}-4.892 * * * \\
(0.905)\end{array}$ & $\begin{array}{c}-4.497 * * * \\
(1.511)\end{array}$ & $\begin{array}{l}-3.580 \\
(2.860)\end{array}$ & $\begin{array}{c}-4.681^{* *} \\
(1.994)\end{array}$ & $\begin{array}{c}-2.587 * * \\
(1.249)\end{array}$ & $\begin{array}{l}-3.423^{*} \\
(1.815)\end{array}$ & $\begin{array}{c}-5.512 \\
(12.882)\end{array}$ & $\begin{array}{l}-1.469 \\
(4.028)\end{array}$ & $\begin{array}{l}-3.050^{*} \\
(1.658)\end{array}$ \\
\hline City & $\begin{array}{c}-4.478^{* * *} \\
(0.825)\end{array}$ & $\begin{array}{c}-5.369 * * * \\
(0.816)\end{array}$ & $\begin{array}{c}-6.369 * * * \\
(1.225)\end{array}$ & $\begin{array}{l}-2.779 \\
(1.979)\end{array}$ & $\begin{array}{c}-4.038 * * * \\
(1.423)\end{array}$ & $\begin{array}{c}-4.792 * * * \\
(0.988)\end{array}$ & $\begin{array}{c}-5.663^{* * *} \\
(1.313)\end{array}$ & $\begin{array}{l}-7.670 \\
(4.667)\end{array}$ & $\begin{array}{c}-9.990 * * * \\
(3.461)\end{array}$ & $\begin{array}{c}-5.876^{* * *} \\
(1.231)\end{array}$ \\
\hline Gymnasium & $\begin{array}{c}-7.110^{* * *} \\
(0.881)\end{array}$ & $\begin{array}{c}-5.673^{* * *} \\
(0.835)\end{array}$ & $\begin{array}{c}-3.143^{* *} \\
(1.379)\end{array}$ & $\begin{array}{c}-9.660 * * * \\
(1.383)\end{array}$ & $\begin{array}{c}-5.867 * * * \\
(1.557)\end{array}$ & $\begin{array}{c}-6.328^{* * *} \\
(1.086)\end{array}$ & $\begin{array}{c}-5.140 * * * \\
(1.225)\end{array}$ & $\begin{array}{c}-7.940^{* *} \\
(3.216)\end{array}$ & $\begin{array}{c}1.183 \\
(3.057)\end{array}$ & $\begin{array}{c}-4.851^{* * *} \\
(1.136)\end{array}$ \\
\hline Lyceum & $\begin{array}{c}-4.456 * * * \\
(1.327)\end{array}$ & $\begin{array}{c}-3.703 * * \\
(1.558)\end{array}$ & $\begin{array}{c}0.208 \\
(2.006)\end{array}$ & $\begin{array}{c}-6.200 * * * \\
(2.236)\end{array}$ & $\begin{array}{c}-8.157 * * * \\
(2.199)\end{array}$ & $\begin{array}{c}-3.669 * * \\
(1.665)\end{array}$ & $\begin{array}{l}-1.393 \\
(2.503)\end{array}$ & $\begin{array}{c}-8.938 * * \\
(4.088)\end{array}$ & $\begin{array}{l}-2.618 \\
(2.988)\end{array}$ & $\begin{array}{l}-1.675 \\
(2.218)\end{array}$ \\
\hline Specialized school & $\begin{array}{l}-4.406 \\
(3.007)\end{array}$ & $\begin{array}{c}-3.843 * * \\
(1.658)\end{array}$ & $\begin{array}{c}-2.548 \\
(3.240)\end{array}$ & $\begin{array}{l}-5.426 \\
(4.284)\end{array}$ & $\begin{array}{l}-5.997^{*} \\
(3.606)\end{array}$ & $\begin{array}{c}-7.059 * * * \\
(1.841)\end{array}$ & $\begin{array}{l}-4.103 \\
(2.963)\end{array}$ & & $\begin{array}{l}-3.838 \\
(7.481)\end{array}$ & $\begin{array}{l}-4.063 \\
(3.233)\end{array}$ \\
\hline Special school & $\begin{array}{l}-2.986 \\
(3.973)\end{array}$ & $\begin{array}{l}-0.166 \\
(2.863)\end{array}$ & $\begin{array}{c}11.041^{* * *} \\
(4.265)\end{array}$ & $\begin{array}{l}-2.821 \\
(5.074)\end{array}$ & $\begin{array}{l}-4.708 \\
(3.573)\end{array}$ & $\begin{array}{c}0.735 \\
(1.160)\end{array}$ & $\begin{array}{c}-4.012 * * \\
(1.753)\end{array}$ & $\begin{array}{c}-8.873 \\
(12.338)\end{array}$ & & $\begin{array}{c}-5.061^{* *} \\
(2.022)\end{array}$ \\
\hline Boarding school & $\begin{array}{c}2.486 \\
(2.430)\end{array}$ & $\begin{array}{c}-0.854 \\
(1.203)\end{array}$ & $\begin{array}{c}0.015 \\
(3.589)\end{array}$ & $\begin{array}{c}1.127 \\
(2.393)\end{array}$ & $\begin{array}{c}4.016 \\
(2.833)\end{array}$ & $\begin{array}{c}1.301 \\
(2.048)\end{array}$ & $\begin{array}{c}3.628 \\
(3.077)\end{array}$ & $\begin{array}{c}-2.431 \\
(4.586) \\
\end{array}$ & $\begin{array}{c}8.229 \\
(8.079)\end{array}$ & $\begin{array}{c}3.827 \\
(3.393)\end{array}$ \\
\hline $\begin{array}{l}\text { R-squared } \\
\text { No. obs. }\end{array}$ & $\begin{array}{c}0.12 \\
1,101 \\
\end{array}$ & $\begin{array}{c}0.11 \\
1,096 \\
\end{array}$ & $\begin{array}{l}0.05 \\
648 \\
\end{array}$ & $\begin{array}{l}0.05 \\
681 \\
\end{array}$ & $\begin{array}{c}0.06 \\
1,059 \\
\end{array}$ & $\begin{array}{r}0.07 \\
944 \\
\end{array}$ & $\begin{array}{l}0.08 \\
607 \\
\end{array}$ & $\begin{array}{c}0.10 \\
105 \\
\end{array}$ & $\begin{array}{l}0.10 \\
179 \\
\end{array}$ & $\begin{array}{l}0.08 \\
745 \\
\end{array}$ \\
\hline \multicolumn{11}{|l|}{ Panel B : FE estimates } \\
\hline & History & Math & Physics & Chemistry & Biology & "Geography & English & French & German & All languages \\
\hline "Minority*Year2010 & $\begin{array}{c}2.123 \\
(1.911)\end{array}$ & $\begin{array}{c}0.874 \\
(2.264)\end{array}$ & $\begin{array}{l}-2.729 \\
(2.874)\end{array}$ & $\begin{array}{l}-8.984 \\
(6.035)\end{array}$ & $\begin{array}{c}0.907 \\
(2.918)\end{array}$ & $\begin{array}{l}-2.729 \\
(3.008)\end{array}$ & $\begin{array}{l}4.847^{*} \\
(2.580)\end{array}$ & $\begin{array}{c}1.675 \\
(9.548)\end{array}$ & $\begin{array}{l}-4.615 \\
(2.908)\end{array}$ & $\begin{array}{c}5.113^{* *} \\
(2.325)\end{array}$ \\
\hline Year2010 & $\begin{array}{c}-1.843^{* * *} \\
(0.627) \\
\end{array}$ & $\begin{array}{c}-1.617 * * \\
(0.704) \\
\end{array}$ & $\begin{array}{c}2.277 \\
(1.574) \\
\end{array}$ & $\begin{array}{c}6.071^{* * *} \\
(1.854) \\
\end{array}$ & $\begin{array}{l}-0.625 \\
(0.947) \\
\end{array}$ & $\begin{array}{c}1.452 \\
(1.041)\end{array}$ & $\begin{array}{l}-1.204 \\
(1.050) \\
\end{array}$ & $\begin{array}{r}7.593 \\
(6.202) \\
\end{array}$ & $\begin{array}{c}4.615 \\
(2.908) \\
\end{array}$ & $\begin{array}{c}-0.547 \\
(0.961) \\
\end{array}$ \\
\hline R-squared & 0.02 & 0.01 & 0.01 & 0.05 & 0.00 & 0.01 & 0.01 & 0.08 & 0.08 & 0.01 \\
\hline No. obs. & 1,044 & 1,04 & 454 & 484 & 990 & 820 & 472 & 60 & 98 & 570 \\
\hline
\end{tabular}


Table 11. The effect of the language policy change on the average test scores, OLS and FE estimates.

Panel A: OLS estimates.

\begin{tabular}{|c|c|c|c|c|c|c|c|c|c|c|}
\hline & History & Math & Physics & "Chemistry & Biology & " Geography & English & French & German & "All languages \\
\hline Minority*Year2010 & $\begin{array}{l}-1.397 \\
(1.222)\end{array}$ & $\begin{array}{c}-0.978 \\
(1.397)\end{array}$ & $\begin{array}{c}3.809 \\
(2.523)\end{array}$ & $\begin{array}{c}3.927 \\
(3.377)\end{array}$ & $\begin{array}{c}1.581 \\
(1.708)\end{array}$ & $\begin{array}{l}-1.952 \\
(1.952)\end{array}$ & $\begin{array}{c}-0.070 \\
(2.270)\end{array}$ & $\begin{array}{l}-1.179 \\
(5.401)\end{array}$ & $\begin{array}{c}-16.024^{*} \\
(8.321)\end{array}$ & $\begin{array}{l}-1.075 \\
(1.890)\end{array}$ \\
\hline Minority & $\begin{array}{c}-4.324 * * * \\
(1.245)\end{array}$ & $\begin{array}{l}-1.532 \\
(1.283)\end{array}$ & $\begin{array}{c}-4.354 * * \\
(2.012)\end{array}$ & $\begin{array}{c}-5.538 * * \\
(2.232)\end{array}$ & $\begin{array}{c}-5.361 * * * \\
(1.533)\end{array}$ & $\begin{array}{l}-0.596 \\
(1.939)\end{array}$ & $\begin{array}{l}-1.006 \\
(2.772)\end{array}$ & $\begin{array}{c}5.757 \\
(4.138)\end{array}$ & $\begin{array}{c}5.668 \\
(8.508)\end{array}$ & $\begin{array}{l}-0.183 \\
(2.408)\end{array}$ \\
\hline Year2010 & $\begin{array}{c}0.553 \\
(0.478)\end{array}$ & $\begin{array}{l}-0.739 \\
(0.549)\end{array}$ & $\begin{array}{c}-3.400 * * * \\
(1.081)\end{array}$ & $\begin{array}{c}-2.363 * * \\
(1.117)\end{array}$ & $\begin{array}{c}-0.446 \\
(0.637)\end{array}$ & $\begin{array}{c}0.599 \\
(0.671)\end{array}$ & $\begin{array}{l}-0.499 \\
(0.746)\end{array}$ & $\begin{array}{l}-2.342 \\
(3.385)\end{array}$ & $\begin{array}{c}-9.112^{* * *} \\
(2.228)\end{array}$ & $\begin{array}{c}-1.610^{* *} \\
(0.749)\end{array}$ \\
\hline Town & $\begin{array}{c}5.439 * * * \\
(1.248)\end{array}$ & $\begin{array}{c}8.344 * * * \\
(1.638)\end{array}$ & $\begin{array}{c}6.862 * * \\
(2.764)\end{array}$ & $\begin{array}{c}5.946 * * * \\
(2.080)\end{array}$ & $\begin{array}{c}5.293 * * * \\
(1.970)\end{array}$ & $\begin{array}{c}0.567 \\
(1.014)\end{array}$ & $\begin{array}{c}6.143^{* * *} \\
(2.242)\end{array}$ & $\begin{array}{c}14.890 * * \\
(7.357)\end{array}$ & $\begin{array}{c}3.119 \\
(4.661)\end{array}$ & $\begin{array}{c}5.828 * * * \\
(2.211)\end{array}$ \\
\hline City & $\begin{array}{c}7.654 * * * \\
(0.955)\end{array}$ & $\begin{array}{c}12.251 * * * \\
(1.243)\end{array}$ & $\begin{array}{c}12.289 * * * \\
(1.921)\end{array}$ & $\begin{array}{c}9.449 * * * \\
(1.894)\end{array}$ & $\begin{array}{c}8.013^{* * *} \\
(1.512)\end{array}$ & $\begin{array}{c}5.016 * * * \\
(0.997)\end{array}$ & $\begin{array}{c}10.420 * * * \\
(1.285)\end{array}$ & $\begin{array}{c}15.068 * * * \\
(2.935)\end{array}$ & $\begin{array}{c}12.928 * * * \\
(4.146)\end{array}$ & $\begin{array}{c}10.669 * * * \\
(1.247)\end{array}$ \\
\hline Gymnasium & $\begin{array}{c}13.315^{* * *} \\
(1.222)\end{array}$ & $\begin{array}{c}12.303 * * * \\
(1.210)\end{array}$ & $\begin{array}{c}10.668 * * * \\
(2.092)\end{array}$ & $\begin{array}{c}12.528 * * * \\
(2.398)\end{array}$ & $\begin{array}{c}11.176 * * * \\
(2.022)\end{array}$ & $\begin{array}{c}10.182 * * * \\
(1.393)\end{array}$ & $\begin{array}{c}13.326 * * * \\
(1.627)\end{array}$ & $\begin{array}{c}14.212 * * * \\
(2.086)\end{array}$ & $\begin{array}{c}16.131 * * * \\
(3.854)\end{array}$ & $\begin{array}{c}13.580 * * * \\
(1.527)\end{array}$ \\
\hline Lyceum & $\begin{array}{c}5.919 * * * \\
(1.981)\end{array}$ & $\begin{array}{c}5.913 * * \\
(2.829)\end{array}$ & $\begin{array}{c}5.013 \\
(4.025)\end{array}$ & $\begin{array}{c}7.210 * * * \\
(2.292)\end{array}$ & $\begin{array}{c}11.088 * * * \\
(2.936)\end{array}$ & $\begin{array}{c}5.155^{* * * *} \\
(1.545)\end{array}$ & $\begin{array}{c}1.390 \\
(2.593)\end{array}$ & $\begin{array}{c}15.914 * * * \\
(3.398)\end{array}$ & $\begin{array}{c}2.394 \\
(7.788)\end{array}$ & $\begin{array}{c}1.602 \\
(2.633)\end{array}$ \\
\hline Specialized school & $\begin{array}{c}4.133 \\
(2.590)\end{array}$ & $\begin{array}{c}10.951^{* * *} \\
(2.940)\end{array}$ & $\begin{array}{c}8.029 \\
(5.376)\end{array}$ & $\begin{array}{c}12.887 * * * \\
(3.280)\end{array}$ & $\begin{array}{c}9.700 * * \\
(3.794)\end{array}$ & $\begin{array}{c}7.547 * * * \\
(2.046)\end{array}$ & $\begin{array}{c}11.115^{* * * *} \\
(4.161)\end{array}$ & & $\begin{array}{l}23.177^{*} \\
(12.367)\end{array}$ & $\begin{array}{c}11.583^{* *} \\
(4.846)\end{array}$ \\
\hline Special school & $\begin{array}{c}5.313 \\
(3.460)\end{array}$ & $\begin{array}{c}7.034 * * * \\
(2.421)\end{array}$ & $\begin{array}{c}5.528 \\
(3.800)\end{array}$ & $\begin{array}{c}-7.286 * * * \\
(2.003)\end{array}$ & $\begin{array}{c}4.573 \\
(3.226)\end{array}$ & $\begin{array}{c}4.196 * * \\
(1.831)\end{array}$ & $\begin{array}{c}11.559 * * * \\
(2.376)\end{array}$ & $\begin{array}{c}12.226 * \\
(6.875)\end{array}$ & & $\begin{array}{c}12.685^{* * * *} \\
(2.194)\end{array}$ \\
\hline Boarding school & $\begin{array}{l}-3.181 \\
(1.976)\end{array}$ & $\begin{array}{l}-4.715^{*} \\
(2.607)\end{array}$ & $\begin{array}{l}-4.986 \\
(4.433)\end{array}$ & $\begin{array}{l}-6.089 \\
(3.867)\end{array}$ & $\begin{array}{c}-7.463 * * * \\
(2.818)\end{array}$ & $\begin{array}{l}-2.233 \\
(2.041)\end{array}$ & $\begin{array}{c}-8.727 * * * \\
(3.104)\end{array}$ & $\begin{array}{c}-15.105^{* * *} \\
(4.437)\end{array}$ & $\begin{array}{c}-26.643 * * \\
(10.817)\end{array}$ & $\begin{array}{c}-10.211^{* * *} \\
(3.656)\end{array}$ \\
\hline $\begin{array}{l}\text { R-squared } \\
\text { No. obs. }\end{array}$ & $\begin{array}{r}0.39 \\
1,101 \\
\end{array}$ & $\begin{array}{r}0.39 \\
1,096 \\
\end{array}$ & $\begin{array}{l}0.25 \\
648 \\
\end{array}$ & $\begin{array}{l}0.17 \\
681 \\
\end{array}$ & $\begin{array}{c}0.21 \\
1,059 \\
\end{array}$ & $\begin{array}{l}0.18 \\
944 \\
\end{array}$ & $\begin{array}{l}0.43 \\
607 \\
\end{array}$ & $\begin{array}{l}0.45 \\
105 \\
\end{array}$ & $\begin{array}{l}0.41 \\
179 \\
\end{array}$ & $\begin{array}{l}0.43 \\
745 \\
\end{array}$ \\
\hline \multicolumn{11}{|c|}{ Panel B: FE estimates. } \\
\hline & " History & "Math & Physics & Chemistry & "Biology & "Geography & English & French & German & "All languages \\
\hline "Minority*Year2010 & $\begin{array}{l}-1.265 \\
(1.182)\end{array}$ & $\begin{array}{l}-1.231 \\
(1.482)\end{array}$ & $\begin{array}{c}2.784 \\
(2.513)\end{array}$ & $\begin{array}{c}5.451 \\
(3.544)\end{array}$ & $\begin{array}{c}0.213 \\
(1.704)\end{array}$ & $\begin{array}{l}-0.363 \\
(2.200)\end{array}$ & $\begin{array}{l}-2.765 \\
(2.443)\end{array}$ & $\begin{array}{l}-0.814 \\
(6.090)\end{array}$ & $\begin{array}{l}-10.626 \\
(9.498)\end{array}$ & $\begin{array}{l}-2.853 \\
(1.841)\end{array}$ \\
\hline Year2010 & $\begin{array}{c}0.350 \\
(0.471)\end{array}$ & $\begin{array}{l}-0.778 \\
(0.553)\end{array}$ & $\begin{array}{c}-3.658 * * * \\
(1.209)\end{array}$ & $\begin{array}{c}-3.015^{* *} \\
(1.190)\end{array}$ & $\begin{array}{c}0.043 \\
(0.608)\end{array}$ & $\begin{array}{c}0.269 \\
(0.692)\end{array}$ & $\begin{array}{c}0.189 \\
(0.770)\end{array}$ & $\begin{array}{l}-3.015 \\
(3.851)\end{array}$ & $\begin{array}{c}-7.727 * * * \\
(2.363)\end{array}$ & $\begin{array}{l}-0.769 \\
(0.782)\end{array}$ \\
\hline $\begin{array}{l}\text { R-squared } \\
\text { No. obs. }\end{array}$ & $\begin{array}{c}0.00 \\
1,044\end{array}$ & $\begin{array}{l}0.01 \\
1,04\end{array}$ & $\begin{array}{l}0.04 \\
454\end{array}$ & $\begin{array}{l}0.03 \\
484\end{array}$ & $\begin{array}{l}0.00 \\
990\end{array}$ & $\begin{array}{l}0.00 \\
820\end{array}$ & $\begin{array}{l}0.01 \\
472\end{array}$ & $\begin{array}{c}0.05 \\
60\end{array}$ & $\begin{array}{c}0.21 \\
98\end{array}$ & $\begin{array}{c}0.01 \\
570\end{array}$ \\
\hline
\end{tabular}

The dependent variables are the average scores in a particular subject. Variable Minority is a dummy indicating minority language schools and captures the difference between the treatment and control group at the baseline. Variable Year2010 is a dummy for the year 2010 and captures the time trend. Variable Minority*Year2010 is the interaction of variable Minority with variable Year2010 and shows the treatment effect. Constant term is included in regressions, but not reported. Cluster-robust standard errors are reported in parentheses. Asterisks denote significance levels: *** - significant at 1\%, ** - significant at 5\% and * - significant at $10 \%$. 
Table 12. Descriptive statistics 2009, Ukrainian schools from Ternopol oblast as the control group, OLS and FE estimates.

\begin{tabular}{|c|c|c|c|c|c|c|c|c|c|c|c|c|c|}
\hline & \multicolumn{6}{|c|}{ Control group (Ukrainian schools) } & \multicolumn{6}{|c|}{ Treatment group (Hungarian and Romanian schools) } & \multirow[t]{2}{*}{ Difference } \\
\hline & mean & St.d & $\min$ & median & $\max$ & $\mathrm{n}$ & mean & St.d & $\min$ & median & $\max$ & $\mathrm{n}$ & \\
\hline Number of pupils & 26.49 & 20.3 & 1 & 21 & 101 & 298 & 17.20 & 11.33 & 1 & 16.5 & 66 & 96 & $9.29 * * *$ \\
\hline No. subjects per pupil & 2.45 & 0.35 & 1.33 & 2.4 & 4.17 & 298 & 2.42 & 0.51 & 1.5 & 2.34 & 4.93 & 96 & 0.03 \\
\hline Town & 0 & 0 & 0 & 0 & 0 & 298 & 0.08 & 0.28 & 0 & 0 & 1 & 96 & $-0.08 * * *$ \\
\hline Gymnasium & 0.04 & 0.19 & 0 & 0 & 1 & 298 & 0.06 & 0.24 & 0 & 0 & 1 & 96 & -0.02 \\
\hline Lyceum & 0.02 & 0.15 & 0 & 0 & 1 & 298 & 0.08 & 0.28 & 0 & 0 & 1 & 96 & $-0.06 * * *$ \\
\hline Specialized & 0.03 & 0.18 & 0 & 0 & 1 & 298 & 0 & 0 & 0 & 0 & 0 & 96 & $0.03 *$ \\
\hline Special & 0.02 & 0.13 & 0 & 0 & 1 & 298 & 0 & 0 & 0 & 0 & 0 & 96 & 0.02 \\
\hline Boarding school & 0.03 & 0.16 & 0 & 0 & 1 & 298 & 0.02 & 0.14 & 0 & 0 & 1 & 96 & 0.01 \\
\hline Takeup English & 0.08 & 0.11 & 0 & 0.04 & 0.69 & 298 & 0.07 & 0.12 & 0 & 0 & 0.51 & 96 & 0.01 \\
\hline Takeup_Biology & 0.25 & 0.18 & 0 & 0.21 & 1 & 298 & 0.30 & 0.24 & 0 & 0.24 & 1 & 96 & -0.05 \\
\hline Takeup_Physics & 0.04 & 0.07 & 0 & 0 & 0.60 & 298 & 0.08 & 0.11 & 0 & 0.04 & 0.56 & 96 & $-0.04 * * *$ \\
\hline Takeup_French & 0 & 0.02 & 0 & 0 & 0.22 & 298 & 0.03 & 0.12 & 0 & 0 & 1 & 96 & $-0.03 * * *$ \\
\hline Takeup_Geography & 0.22 & 0.17 & 0 & 0.20 & 0.86 & 298 & 0.12 & 0.17 & 0 & 0.07 & 1 & 96 & $0.1 * * *$ \\
\hline Takeup_Chemistry & 0.08 & 0.08 & 0 & 0.07 & 0.50 & 298 & 0.09 & 0.15 & 0 & 0.05 & 1 & 96 & -0.01 \\
\hline Takeup_History & 0.35 & 0.19 & 0 & 0.33 & 1 & 298 & 0.34 & 0.23 & 0 & 0.33 & 1 & 96 & 0.01 \\
\hline Takeup_Math & 0.40 & 0.21 & 0 & 0.39 & 1 & 298 & 0.39 & 0.24 & 0 & 0.36 & 1 & 96 & 0.01 \\
\hline Takeup_German & 0.01 & 0.05 & 0 & 0 & 0.54 & 298 & 0.01 & 0.03 & 0 & 0 & 0.17 & 96 & 0 \\
\hline Takeup_Ukrainian & 1 & 0 & 1 & 1 & 1 & 298 & 1 & 0 & 1 & 1 & 1 & 96 & 0 \\
\hline Failed English & 0.07 & 0.19 & 0 & 0 & 1 & 173 & 0.09 & 0.16 & 0 & 0 & 0.50 & 33 & -0.02 \\
\hline Failed_Physics & 0.04 & 0.16 & 0 & 0 & 1 & 124 & 0.07 & 0.18 & 0 & 0 & 1 & 54 & -0.03 \\
\hline Failed_French & 0.00 & 0.00 & 0 & 0 & 0 & 8 & 0.03 & 0.12 & 0 & 0 & 0.50 & 19 & -0.03 \\
\hline Failed_Geography & 0.06 & 0.15 & 0 & 0 & 1 & 263 & 0.08 & 0.17 & 0 & 0 & 0.67 & 58 & -0.01 \\
\hline Failed_Chemistry & 0.03 & 0.13 & 0 & 0 & 1 & 224 & 0.15 & 0.28 & 0 & 0 & 1 & 55 & $-0.12 * * *$ \\
\hline Failed_History & 0.07 & 0.11 & 0 & 0 & 0.67 & 284 & 0.13 & 0.16 & 0 & 0.08 & 0.75 & 85 & $-0.06 * * *$ \\
\hline Failed_Math & 0.05 & 0.10 & 0 & 0 & 1 & 287 & 0.12 & 0.22 & 0 & 0 & 1 & 91 & $-0.07 * * *$ \\
\hline Failed_German & 0.00 & 0.00 & 0 & 0 & 0 & 54 & 0.00 & 0.00 & 0 & 0 & 0 & 8 & 0.00 \\
\hline Failed_Ukrainian & 0.07 & 0.09 & 0 & 0.04 & 1 & 298 & 0.37 & 0.24 & 0 & 0.35 & 1 & 96 & $-0.30 * * *$ \\
\hline Score English & 149.30 & 13.78 & 111.75 & 149.17 & 186.75 & 173 & 147.29 & 15.22 & 120.75 & 143 & 180.92 & 33 & 2.01 \\
\hline Score_Biology & 155.46 & 13.10 & 111.75 & 155.13 & 197.50 & 284 & 143.89 & 15.25 & 111.75 & 143 & 174.69 & 84 & $11.57 * * *$ \\
\hline Score_Physics & 157.60 & 15.65 & 111.75 & 158.28 & 188.75 & 124 & 146.93 & 15.69 & 111.75 & 143 & 182.38 & 54 & $10.67 * * *$ \\
\hline Score_French & 161.78 & 18.23 & 136.38 & 160.44 & 192.75 & 8 & 151.76 & 15.09 & 133.88 & 143 & 178 & 19 & 10.02 \\
\hline Score_Geography & 153.98 & 13.57 & 111.75 & 154.80 & 197.50 & 263 & 149.08 & 15.59 & 117.75 & 147.1 & 186.75 & 58 & $4.9 * *$ \\
\hline Score_Chemistry & 159.49 & 14.95 & 111.75 & 161.56 & 187.4 & 224 & 147.11 & 18.71 & 111.75 & 146.06 & 197.5 & 55 & $12.38 * * *$ \\
\hline Score_History & 156.47 & 10.72 & 129.75 & 156.00 & 186.75 & 284 & 143.81 & 11.69 & 116.25 & 142.9 & 186.75 & 85 & $12.66^{* * *}$ \\
\hline Score_Math & 158.00 & 10.74 & 111.75 & 159.41 & 186.75 & 287 & 146.85 & 13.53 & 111.75 & 145.95 & 192.75 & 91 & $11.15^{* * *}$ \\
\hline Score_German & 162.47 & 17.09 & 129.75 & 157.41 & 197.50 & 54 & 155.44 & 20.22 & 129.75 & 155 & 189 & 8 & 7.03 \\
\hline Score_Ukrainian & 155.43 & 9.21 & 111.75 & 155.55 & 182.53 & 298 & 131.35 & 10.06 & 111.75 & 129.75 & 159.92 & 96 & $24.08 * * *$ \\
\hline
\end{tabular}

Asterisks denote significance levels: *** - significant at 1\%, ** - significant at 5\% and * - significant at $10 \%$. 
Table 13. The effect of the language policy change on participation in final tests and average number of subjects chosen, OLS and FE estimates.

\begin{tabular}{|c|c|c|c|c|}
\hline & \multicolumn{2}{|c|}{$\begin{array}{c}\text { Dependent variable: } \\
\text { Participation in final tests } \\
\end{array}$} & \multicolumn{2}{|c|}{$\begin{array}{c}\text { Dependent variable: } \\
\text { Average number of subjects chosen }\end{array}$} \\
\hline & OLS & FE & OLS & $\mathrm{FE}$ \\
\hline & (1) & (2) & (3) & (4) \\
\hline Minority*Year2010 & $\begin{array}{l}-0.101 \\
(1.090)\end{array}$ & $\begin{array}{l}-0.209 \\
(1.024)\end{array}$ & $\begin{array}{c}-0.292^{* * *} \\
(0.074)\end{array}$ & $\begin{array}{c}-0.270^{* * *} \\
(0.073)\end{array}$ \\
\hline Minority & $\begin{array}{c}-7.518^{* * *} \\
(1.665)\end{array}$ & & $\begin{array}{c}0.019 \\
(0.070)\end{array}$ & \\
\hline Year2010 & $\begin{array}{c}-3.318^{* * *} \\
(0.686)\end{array}$ & $\begin{array}{c}-3.086^{* * *} \\
(0.622)\end{array}$ & $\begin{array}{c}1.004 * * * \\
(0.024)\end{array}$ & $\begin{array}{c}0.998 * * * \\
(0.024)\end{array}$ \\
\hline Town & $\begin{array}{c}6.372 \\
(4.350)\end{array}$ & & $\begin{array}{c}0.221 * * * \\
(0.084)\end{array}$ & \\
\hline City & $\begin{array}{c}27.791 * * * \\
(3.992)\end{array}$ & & $\begin{array}{c}0.237 * * * \\
(0.028)\end{array}$ & \\
\hline Gymnasium & $\begin{array}{c}6.299 \\
(4.583)\end{array}$ & & $\begin{array}{l}0.101^{* *} \\
(0.043)\end{array}$ & \\
\hline Lyceum & $\begin{array}{c}4.712 \\
(3.609)\end{array}$ & & $\begin{array}{c}0.315 * * * \\
(0.110)\end{array}$ & \\
\hline Specialized school & $\begin{array}{c}9.440 \\
(7.064)\end{array}$ & & $\begin{array}{l}-0.060 \\
(0.054)\end{array}$ & \\
\hline Special school & $\begin{array}{l}-13.883 \\
(8.632)\end{array}$ & & $\begin{array}{l}-0.039 \\
(0.149)\end{array}$ & \\
\hline Boarding school & $\begin{array}{l}-1.747 \\
(4.287)\end{array}$ & & $\begin{array}{c}0.301^{* *} \\
(0.122)\end{array}$ & \\
\hline Intercept & $\begin{array}{c}22.566 * * * \\
(0.953) \\
\end{array}$ & $\begin{array}{c}24.320^{* * *} \\
(0.255) \\
\end{array}$ & $\begin{array}{c}2.397 * * * \\
(0.021)\end{array}$ & $\begin{array}{c}2.476^{* * *} \\
(0.012) \\
\end{array}$ \\
\hline $\begin{array}{l}\text { R-squared } \\
\text { No. obs. }\end{array}$ & $\begin{array}{l}0.32 \\
802\end{array}$ & $\begin{array}{l}0.09 \\
774\end{array}$ & $\begin{array}{l}0.69 \\
802\end{array}$ & $\begin{array}{l}0.84 \\
774\end{array}$ \\
\hline
\end{tabular}

The dependent variables indicate the number of students from each school participating in the EIT or the average number of subjects chosen by students in each school. Variable Minority is a dummy indicating minority language schools and captures the difference between the treatment and control group at the baseline. Variable Year2010 is a dummy for the year 2010 and captures the time trend. Variable Minority*Year2010 is the interaction of variable Minority with variable Year2010 and shows the treatment effect. Cluster-robust standard errors are reported in parentheses. Asterisks denote significance levels: *** - significant at $1 \%$, ** - significant at $5 \%$ and ${ }^{*}$ - significant at $10 \%$. 
Table 14. The effect of the language policy change on the failure rates and average scores in the Ukrainian language and literature exam, OLS and FE estimates.

\begin{tabular}{|c|c|c|c|c|}
\hline & \multicolumn{2}{|c|}{$\begin{array}{l}\text { Dependent variable: } \\
\text { Failed_Ukrainian }\end{array}$} & \multicolumn{2}{|c|}{$\begin{array}{c}\text { Dependent variable: } \\
\text { Score_Ukrainian }\end{array}$} \\
\hline & OLS & FE & OLS & $\mathrm{FE}$ \\
\hline & $(1)$ & $(2)$ & (3) & (4) \\
\hline Minority*Year2010 & $\begin{array}{l}-3.831^{*} \\
-1.978\end{array}$ & $\begin{array}{l}-2.701 \\
-1.891\end{array}$ & $\begin{array}{c}3.780 * * * \\
(0.964)\end{array}$ & $\begin{array}{c}3.569 * * * \\
(0.906)\end{array}$ \\
\hline Minority & $\begin{array}{l}26.820 * * * \\
-2.025\end{array}$ & & $\begin{array}{c}-23.760 * * * \\
-1.108\end{array}$ & \\
\hline Year2010 & $\begin{array}{l}0.838 * * \\
(0.410)\end{array}$ & $\begin{array}{c}0.639 \\
(0.398)\end{array}$ & $\begin{array}{c}-1.735^{* * *} \\
(0.451)\end{array}$ & $\begin{array}{c}-1.781^{* * *} \\
(0.420)\end{array}$ \\
\hline Town & $\begin{array}{c}4.626 \\
-8.790\end{array}$ & & $\begin{array}{l}-0.233 \\
-4.920\end{array}$ & \\
\hline City & $\begin{array}{c}-3.025 * * * \\
(0.685)\end{array}$ & & $\begin{array}{c}4.750 * * * \\
(0.854)\end{array}$ & \\
\hline Gymnasium & $\begin{array}{l}-9.004 * * * \\
-2.202\end{array}$ & & $\begin{array}{c}15.620 * * * \\
-2.073\end{array}$ & \\
\hline Lyceum & $\begin{array}{l}-2.493 \\
-2.082\end{array}$ & & $\begin{array}{c}5.128 * * * \\
-1.841\end{array}$ & \\
\hline Specialized school & $\begin{array}{c}-2.784 * * * \\
(0.934)\end{array}$ & & $\begin{array}{c}8.498 * * * \\
-2.258\end{array}$ & \\
\hline Special school & $\begin{array}{l}-5.090 \\
-5.214\end{array}$ & & $\begin{array}{c}6.801 \\
-5.936\end{array}$ & \\
\hline Boarding school & $\begin{array}{l}4.176 \\
-3.723\end{array}$ & & $\begin{array}{l}-2.718 \\
-2.463\end{array}$ & \\
\hline Intercept & $\begin{array}{c}7.178 * * * \\
(0.530)\end{array}$ & $\begin{array}{c}10.229 * * * \\
(0.227)\end{array}$ & $\begin{array}{c}155.104^{* * *} \\
(0.591)\end{array}$ & $\begin{array}{c}153.935 * * * \\
(0.187)\end{array}$ \\
\hline $\begin{array}{l}\text { R-squared } \\
\text { No. obs. }\end{array}$ & $\begin{array}{l}0.51 \\
802 \\
\end{array}$ & $\begin{array}{l}.01 \\
774 \\
\end{array}$ & $\begin{array}{l}0.63 \\
802 \\
\end{array}$ & $\begin{array}{l}0.06 \\
774 \\
\end{array}$ \\
\hline
\end{tabular}

The dependent variables indicate the percentage of students failing the test in Ukrainian language and literature (Failed_Ukrainian) and the average score in that test (Score_Ukrainian) for each school. Variable Minority is a dummy indicating minority language schools and captures the difference between the treatment and control group at the baseline. Variable Year2010 is a dummy for the year 2010 and captures the time trend. Variable Minority*Year2010 is the interaction of variable Minority with variable Year2010 and shows the treatment effect. Cluster-robust standard errors are reported in parentheses. Asterisks denote significance levels: ${ }^{* * *}$ - significant at $1 \%,{ }^{* *}$ significant at $5 \%$ and $*$ - significant at $10 \%$. 
Table 15. The effect of the language policy change on the take-up of particular subjects, OLS estimates.

Panel A: OLS estimates.

\begin{tabular}{|c|c|c|c|c|c|c|c|c|c|c|}
\hline & History & "Math & Physics & "Chemistry & Biology & "Geography & English & French & " German & "All languages \\
\hline Minority*Year2010 & $\begin{array}{c}-0.105 * * * \\
(0.032)\end{array}$ & $\begin{array}{l}-0.057^{*} \\
(0.034)\end{array}$ & $\begin{array}{c}-0.024 \\
(0.038)\end{array}$ & $\begin{array}{c}0.042 \\
(0.061)\end{array}$ & $\begin{array}{c}-0.081^{* *} \\
(0.039)\end{array}$ & $\begin{array}{c}-0.094 * * \\
(0.047)\end{array}$ & $\begin{array}{c}0.006 \\
(0.046)\end{array}$ & $\begin{array}{c}0.031 \\
(0.078)\end{array}$ & $\begin{array}{c}0.040 \\
(0.052)\end{array}$ & $\begin{array}{c}0.019 \\
(0.038)\end{array}$ \\
\hline Minority & $\begin{array}{c}0.051 \\
(0.032)\end{array}$ & $\begin{array}{c}0.010 \\
(0.031)\end{array}$ & $\begin{array}{c}0.086 * * * \\
(0.029)\end{array}$ & $\begin{array}{c}0.055^{* *} \\
(0.027)\end{array}$ & $\begin{array}{c}0.106 * * * \\
(0.033)\end{array}$ & $\begin{array}{l}-0.010 \\
(0.047)\end{array}$ & $\begin{array}{c}0.116 * * \\
(0.058)\end{array}$ & $\begin{array}{c}0.083 \\
(0.073)\end{array}$ & $\begin{array}{c}0.008 \\
(0.026)\end{array}$ & $\begin{array}{l}0.083^{*} \\
(0.045)\end{array}$ \\
\hline Year2010 & $\begin{array}{c}0.408 * * * \\
(0.012)\end{array}$ & $\begin{array}{c}0.120^{* * *} \\
(0.013)\end{array}$ & $\begin{array}{c}0.046^{* * *} \\
(0.012)\end{array}$ & $\begin{array}{c}0.009 \\
(0.010)\end{array}$ & $\begin{array}{c}0.079 * * * \\
(0.015)\end{array}$ & $\begin{array}{c}0.228 * * * \\
(0.015)\end{array}$ & $\begin{array}{c}0.102^{* * *} \\
(0.012)\end{array}$ & $\begin{array}{l}-0.047 \\
(0.034)\end{array}$ & $\begin{array}{l}-0.016 \\
(0.044)\end{array}$ & $\begin{array}{c}0.093^{* * *} \\
(0.013)\end{array}$ \\
\hline Town & $\begin{array}{l}-0.041 \\
(0.035)\end{array}$ & $\begin{array}{c}0.025 \\
(0.068)\end{array}$ & $\begin{array}{c}-0.078 * * * \\
(0.030)\end{array}$ & $\begin{array}{c}-0.120 * * * \\
(0.033)\end{array}$ & $\begin{array}{l}-0.067 \\
(0.063)\end{array}$ & $\begin{array}{c}-0.055 \\
(0.034)\end{array}$ & $\begin{array}{c}0.006 \\
(0.052)\end{array}$ & 0.000 & $\begin{array}{c}0.009 \\
(0.026)\end{array}$ & $\begin{array}{c}0.087 * * \\
(0.039)\end{array}$ \\
\hline City & $\begin{array}{l}-0.013 \\
(0.013)\end{array}$ & $\begin{array}{c}0.055 * * \\
(0.022)\end{array}$ & $\begin{array}{c}-0.043^{* *} \\
(0.019)\end{array}$ & $\begin{array}{c}-0.053 * * * \\
(0.010)\end{array}$ & $\begin{array}{c}-0.080 * * * \\
(0.025)\end{array}$ & $\begin{array}{c}0.020 \\
(0.020)\end{array}$ & $\begin{array}{c}0.073^{* * *} * \\
(0.022)\end{array}$ & $\begin{array}{c}-0.063^{* *} \\
(0.029)\end{array}$ & $\begin{array}{l}-0.014 \\
(0.024)\end{array}$ & $\begin{array}{c}0.086 * * * \\
(0.020)\end{array}$ \\
\hline Gymnasium & $\begin{array}{l}-0.010 \\
(0.016)\end{array}$ & $\begin{array}{l}-0.003 \\
(0.051)\end{array}$ & $\begin{array}{l}-0.025 \\
(0.021)\end{array}$ & $\begin{array}{l}-0.017 \\
(0.012)\end{array}$ & $\begin{array}{c}-0.113^{* * *} \\
(0.020)\end{array}$ & $\begin{array}{c}-0.120 * * * \\
(0.023)\end{array}$ & $\begin{array}{c}0.184 * * * \\
(0.041)\end{array}$ & $\begin{array}{c}-0.009 \\
(0.034)\end{array}$ & $\begin{array}{l}-0.001 \\
(0.015)\end{array}$ & $\begin{array}{c}0.207 * * * \\
(0.036)\end{array}$ \\
\hline Lyceum & $\begin{array}{l}-0.001 \\
(0.045)\end{array}$ & $\begin{array}{c}0.090 \\
(0.088)\end{array}$ & $\begin{array}{c}0.014 \\
(0.028)\end{array}$ & $\begin{array}{c}0.032 \\
(0.028)\end{array}$ & $\begin{array}{c}0.064 \\
(0.079)\end{array}$ & $\begin{array}{c}-0.002 \\
(0.047)\end{array}$ & $\begin{array}{c}0.046 \\
(0.036)\end{array}$ & $\begin{array}{c}-0.118^{* * *} \\
(0.031)\end{array}$ & $\begin{array}{l}-0.020 \\
(0.026)\end{array}$ & $\begin{array}{l}0.077^{*} \\
(0.043)\end{array}$ \\
\hline Specialized school & $\begin{array}{l}-0.020 \\
(0.026)\end{array}$ & $\begin{array}{c}-0.149 * * * \\
(0.030)\end{array}$ & $\begin{array}{c}-0.067 * * * \\
(0.014)\end{array}$ & $\begin{array}{c}0.001 \\
(0.014)\end{array}$ & $\begin{array}{c}-0.105^{* * *} \\
(0.023)\end{array}$ & $\begin{array}{c}-0.189 * * * \\
(0.035)\end{array}$ & $\begin{array}{c}0.354^{* * *} * \\
(0.055)\end{array}$ & $\begin{array}{l}-0.035 \\
(0.042)\end{array}$ & $\begin{array}{c}0.299 * * * \\
(0.073)\end{array}$ & $\begin{array}{c}0.359 * * * \\
(0.049)\end{array}$ \\
\hline Special school & $\begin{array}{c}0.092 \\
(0.065)\end{array}$ & $\begin{array}{c}0.036 \\
(0.079)\end{array}$ & $\begin{array}{c}-0.346 * * * \\
(0.038)\end{array}$ & $\begin{array}{l}-0.005 \\
(0.032)\end{array}$ & $\begin{array}{l}-0.016 \\
(0.120)\end{array}$ & $\begin{array}{c}-0.152 * \\
(0.087)\end{array}$ & $\begin{array}{c}0.188 * * * \\
(0.064)\end{array}$ & 0.000 & $\begin{array}{l}-0.031 \\
(0.028)\end{array}$ & $\begin{array}{c}0.167 * * \\
(0.079)\end{array}$ \\
\hline Boarding school & $\begin{array}{l}-0.071 \\
(0.060)\end{array}$ & $\begin{array}{l}-0.009 \\
(0.063)\end{array}$ & $\begin{array}{c}0.230 * * * \\
(0.033)\end{array}$ & $\begin{array}{l}-0.051 \\
(0.031)\end{array}$ & $\begin{array}{c}0.060 \\
(0.075)\end{array}$ & $\begin{array}{c}0.176 * * * \\
(0.034)\end{array}$ & $\begin{array}{c}-0.063 \\
(0.053) \\
\end{array}$ & $\begin{array}{c}0.379 * * * \\
(0.019)\end{array}$ & $\begin{array}{l}-0.031 \\
(0.022)\end{array}$ & $\begin{array}{l}-0.016 \\
(0.072)\end{array}$ \\
\hline $\begin{array}{l}\text { R-squared } \\
\text { No. obs. }\end{array}$ & $\begin{array}{l}0.66 \\
771 \\
\end{array}$ & $\begin{array}{l}0.14 \\
770 \\
\end{array}$ & $\begin{array}{l}0.24 \\
399 \\
\end{array}$ & $\begin{array}{l}0.13 \\
514 \\
\end{array}$ & $\begin{array}{l}0.14 \\
743 \\
\end{array}$ & $\begin{array}{l}0.35 \\
686 \\
\end{array}$ & $\begin{array}{l}0.62 \\
427 \\
\end{array}$ & $\begin{array}{c}0.24 \\
71 \\
\end{array}$ & $\begin{array}{l}0.54 \\
134 \\
\end{array}$ & $\begin{array}{l}0.64 \\
530 \\
\end{array}$ \\
\hline \multicolumn{11}{|l|}{ Panel B: FE estimates. } \\
\hline & 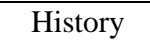 & Math & Physics & Chemistry & Biology & Geography & English & French & German & All languages \\
\hline Minority*Year2010 & $\begin{array}{c}-0.084^{* * *} \\
(0.030)\end{array}$ & $\begin{array}{l}-0.056^{*} \\
(0.033)\end{array}$ & $\begin{array}{c}-0.072^{*} \\
(0.037)\end{array}$ & $\begin{array}{c}0.053 \\
(0.064)\end{array}$ & $\begin{array}{c}-0.041 \\
(0.037)\end{array}$ & $\begin{array}{c}-0.085 * * \\
(0.041)\end{array}$ & $\begin{array}{c}0.048 \\
(0.042)\end{array}$ & $\begin{array}{c}0.056 \\
(0.074)\end{array}$ & $\begin{array}{c}0.080 \\
(0.082)\end{array}$ & $\begin{array}{l}0.061^{*} \\
(0.034)\end{array}$ \\
\hline Year2010 & $\begin{array}{c}0.434 * * * \\
(0.011)\end{array}$ & $\begin{array}{c}0.126^{* * *} \\
(0.013)\end{array}$ & $\begin{array}{c}0.060^{* * *} \\
(0.013)\end{array}$ & $\begin{array}{c}0.003 \\
(0.009)\end{array}$ & $\begin{array}{c}0.082^{* * * *} \\
(0.012)\end{array}$ & $\begin{array}{c}0.270 * * * \\
(0.015)\end{array}$ & $\begin{array}{c}0.102 * * * \\
(0.012)\end{array}$ & $\begin{array}{l}-0.033 \\
(0.050)\end{array}$ & $\begin{array}{l}-0.052 \\
(0.069)\end{array}$ & $\begin{array}{c}0.093 * * * \\
(0.013)\end{array}$ \\
\hline R-squared & 0.85 & 0.26 & 0.12 & 0.028 & 0.13 & 0.64 & 0.46 & 0.03 & 0.10 & 0.41 \\
\hline
\end{tabular}

The dependent variables are the percentages of students (among those participating in the test = taking the Ukrainian language and literature test) taking a particular subject. Variable Minority is a dummy indicating minority language schools and captures the difference between the treatment and control group at the baseline. Variable Year2010 is a dummy for the year 2010 and captures the time trend. Variable Minority*Year2010 is the interaction of variable Minority with variable Year2010 and shows the treatment effect. Constant term is included in regressions, but not reported. Cluster-robust standard errors are reported in parentheses. Asterisks denote significance levels: *** significant at $1 \%$, ** - significant at $5 \%$ and $*$ - significant at $10 \%$. 
Table 16. The effect of the language policy change on the test failure rates, OLS and FE estimates.

Panel A: OLS estimates.

\begin{tabular}{|c|c|c|c|c|c|c|c|c|c|c|}
\hline & History & Math & Physics & Chemistry & "Biology & "Geography & English & "French & German & All languages \\
\hline Minority*Year2010 & $\begin{array}{l}-0.057 \\
(1.991)\end{array}$ & $\begin{array}{l}-1.713 \\
(2.144)\end{array}$ & $\begin{array}{l}-1.690 \\
(2.837)\end{array}$ & $\begin{array}{l}-3.648 \\
(4.987)\end{array}$ & $\begin{array}{c}0.308 \\
(2.809)\end{array}$ & $\begin{array}{c}1.909 \\
(3.501)\end{array}$ & $\begin{array}{c}-0.067 \\
(2.843)\end{array}$ & $\begin{array}{c}7.314 \\
(7.670)\end{array}$ & $\begin{array}{c}-0.507 \\
(3.126)\end{array}$ & $\begin{array}{c}0.785 \\
(2.431)\end{array}$ \\
\hline Minority & $\begin{array}{c}7.908^{* * *} \\
(1.989)\end{array}$ & $\begin{array}{c}6.944 * * * \\
(1.773)\end{array}$ & $\begin{array}{c}2.507 \\
(2.310)\end{array}$ & $\begin{array}{c}10.711 * * * \\
(3.609)\end{array}$ & $\begin{array}{c}10.266 * * * \\
(2.560)\end{array}$ & $\begin{array}{c}5.298 \\
(3.569)\end{array}$ & $\begin{array}{c}2.782 \\
(2.754)\end{array}$ & $\begin{array}{c}3.064 \\
(3.303)\end{array}$ & $\begin{array}{l}-1.502 \\
(1.241)\end{array}$ & $\begin{array}{c}1.773 \\
(2.068)\end{array}$ \\
\hline Year2010 & $\begin{array}{c}-0.442 \\
(0.628)\end{array}$ & $\begin{array}{c}1.374 * * \\
(0.591)\end{array}$ & $\begin{array}{l}-0.113 \\
(1.712)\end{array}$ & $\begin{array}{c}1.093 \\
(1.349)\end{array}$ & $\begin{array}{c}-1.799 * * \\
(0.875)\end{array}$ & $\begin{array}{c}1.490^{* *} \\
(0.702)\end{array}$ & $\begin{array}{l}1.216 \\
(0.874)\end{array}$ & $\begin{array}{l}-2.076 \\
(1.666)\end{array}$ & $\begin{array}{c}4.069 * * \\
(1.938)\end{array}$ & $\begin{array}{l}1.393^{*} \\
(0.799)\end{array}$ \\
\hline Town & $\begin{array}{l}-4.487 * \\
(2.627)\end{array}$ & $\begin{array}{c}-8.681 * * * \\
(1.607)\end{array}$ & $\begin{array}{c}2.717 \\
(4.851)\end{array}$ & $\begin{array}{c}-11.425^{* * *} \\
(2.840)\end{array}$ & $\begin{array}{c}-9.192 * * * \\
(1.985)\end{array}$ & $\begin{array}{c}-8.578 * * * \\
(2.723)\end{array}$ & $\begin{array}{c}0.433 \\
(2.824)\end{array}$ & 0.000 & $\begin{array}{c}3.826 \\
(3.395)\end{array}$ & $\begin{array}{c}1.032 \\
(2.318)\end{array}$ \\
\hline City & $\begin{array}{c}-2.671 * * * \\
(0.601)\end{array}$ & $\begin{array}{c}-1.819 * * * \\
(0.624)\end{array}$ & $\begin{array}{c}0.815 \\
(1.936)\end{array}$ & $\begin{array}{c}-0.324 \\
(1.761)\end{array}$ & $\begin{array}{c}-2.095^{* *} \\
(0.964)\end{array}$ & $\begin{array}{l}-1.062 \\
(0.881)\end{array}$ & $\begin{array}{l}-1.249 \\
(1.176)\end{array}$ & $\begin{array}{c}4.924 \\
(3.363)\end{array}$ & $\begin{array}{c}0.304 \\
(2.499)\end{array}$ & $\begin{array}{l}-0.947 \\
(1.129)\end{array}$ \\
\hline Gymnasium & $\begin{array}{c}-6.132 * * * \\
(0.837)\end{array}$ & $\begin{array}{c}-2.733^{* * *} \\
(1.037)\end{array}$ & $\begin{array}{c}-6.899 * * * \\
(1.511)\end{array}$ & $\begin{array}{c}-5.746 * * * \\
(0.900)\end{array}$ & $\begin{array}{c}-4.191 * * * \\
(1.405)\end{array}$ & $\begin{array}{c}-5.833 * * * \\
(1.084)\end{array}$ & $\begin{array}{c}-5.336 * * * \\
(1.071)\end{array}$ & $\begin{array}{l}-6.707^{*} \\
(3.856)\end{array}$ & $\begin{array}{c}-0.813 \\
(1.805)\end{array}$ & $\begin{array}{c}-4.998 * * * \\
(0.984)\end{array}$ \\
\hline Lyceum & $\begin{array}{c}-5.330 * * * \\
(1.459)\end{array}$ & $\begin{array}{c}-6.006 * * * \\
(1.122)\end{array}$ & $\begin{array}{c}-4.004^{* *} \\
(1.933)\end{array}$ & $\begin{array}{c}-7.031^{* * *} \\
(2.556)\end{array}$ & $\begin{array}{c}-9.058 * * * \\
(2.294)\end{array}$ & $\begin{array}{c}-4.361^{* *} \\
(1.767)\end{array}$ & $\begin{array}{l}-2.037 \\
(1.873)\end{array}$ & $\begin{array}{l}-8.329 \\
(5.047)\end{array}$ & $\begin{array}{c}-2.601^{* *} \\
(1.262)\end{array}$ & $\begin{array}{l}-2.275 \\
(1.571)\end{array}$ \\
\hline Specialized school & $\begin{array}{c}-2.150 * * * \\
(0.828)\end{array}$ & $\begin{array}{c}-2.125 * * * \\
(0.787)\end{array}$ & $\begin{array}{c}-6.049 * * * \\
(1.425)\end{array}$ & $\begin{array}{l}-1.860 \\
(2.549)\end{array}$ & $\begin{array}{c}-4.309 * * * \\
(1.218)\end{array}$ & $\begin{array}{l}-0.735 \\
(1.502)\end{array}$ & $\begin{array}{c}-5.412 * * * \\
(1.097)\end{array}$ & $\begin{array}{l}-7.026 \\
(4.320)\end{array}$ & $\begin{array}{l}-2.144 \\
(1.978)\end{array}$ & $\begin{array}{c}-5.160 * * * \\
(1.052)\end{array}$ \\
\hline Special school & $\begin{array}{c}2.605 \\
(4.986)\end{array}$ & $\begin{array}{c}1.905 \\
(3.606)\end{array}$ & $\begin{array}{c}22.627 * * \\
(9.330)\end{array}$ & $\begin{array}{l}-9.200 * \\
(5.095)\end{array}$ & $\begin{array}{c}5.655 \\
(4.516)\end{array}$ & $\begin{array}{c}4.830 \\
(5.090)\end{array}$ & $\begin{array}{l}-0.396 \\
(5.501)\end{array}$ & 0.000 & $\begin{array}{c}-4.171^{*} \\
(2.210)\end{array}$ & $\begin{array}{l}-0.338 \\
(4.577)\end{array}$ \\
\hline Boarding school & $\begin{array}{c}-4.433 \\
(3.081)\end{array}$ & $\begin{array}{l}-1.051 \\
(1.818)\end{array}$ & $\begin{array}{l}-3.107 \\
(2.162)\end{array}$ & $\begin{array}{c}3.560 \\
(4.981)\end{array}$ & $\begin{array}{c}-1.624 \\
(3.069)\end{array}$ & $\begin{array}{l}-2.958 \\
(3.007) \\
\end{array}$ & $\begin{array}{c}-3.869 \\
(3.890)\end{array}$ & $\begin{array}{l}-2.076 \\
(2.311)\end{array}$ & $\begin{array}{c}0.755 \\
(1.506) \\
\end{array}$ & $\begin{array}{l}-3.646 \\
(3.018)\end{array}$ \\
\hline $\begin{array}{l}\text { R-squared } \\
\text { No. obs. }\end{array}$ & $\begin{array}{l}0.16 \\
771 \\
\end{array}$ & $\begin{array}{l}0.11 \\
770 \\
\end{array}$ & $\begin{array}{l}0.04 \\
399 \\
\end{array}$ & $\begin{array}{l}0.07 \\
514 \\
\end{array}$ & $\begin{array}{l}0.13 \\
743 \\
\end{array}$ & $\begin{array}{l}0.06 \\
686 \\
\end{array}$ & $\begin{array}{l}0.09 \\
427 \\
\end{array}$ & $\begin{array}{c}0.07 \\
71 \\
\end{array}$ & $\begin{array}{l}0.04 \\
134 \\
\end{array}$ & $\begin{array}{l}0.08 \\
530 \\
\end{array}$ \\
\hline \multicolumn{11}{|c|}{ Panel B: FE estimates. } \\
\hline & " History & "Math & Physics & "Chemistry & "Biology & " Geography & English & "French & German & All languages \\
\hline Minority*Year2010 & $\begin{array}{c}0.672 \\
(1.921)\end{array}$ & $\begin{array}{l}-2.187 \\
(2.231)\end{array}$ & $\begin{array}{c}-0.075 \\
(3.195)\end{array}$ & $\begin{array}{l}-4.230 \\
(5.887)\end{array}$ & $\begin{array}{c}1.695 \\
(2.896)\end{array}$ & $\begin{array}{l}-3.054 \\
(2.927)\end{array}$ & $\begin{array}{c}2.743 \\
(2.578)\end{array}$ & $\begin{array}{c}9.267 \\
(7.434)\end{array}$ & $\begin{array}{l}-2.336 \\
(1.839)\end{array}$ & $\begin{array}{c}3.377 \\
(2.323)\end{array}$ \\
\hline Year2010 & $\begin{array}{c}-0.391 \\
(0.650)\end{array}$ & $\begin{array}{c}1.444^{* *} \\
(0.586)\end{array}$ & $\begin{array}{c}-0.377 \\
(2.095)\end{array}$ & $\begin{array}{c}1.317 \\
(1.263)\end{array}$ & $\begin{array}{l}-1.413 \\
(0.867) \\
\end{array}$ & $\begin{array}{c}1.776^{* *} \\
(0.766) \\
\end{array}$ & $\begin{array}{c}0.900 \\
(1.037)\end{array}$ & $\begin{array}{l}-0.000 \\
(0.000)\end{array}$ & $\begin{array}{c}2.336 \\
(1.839) \\
\end{array}$ & $\begin{array}{c}1.188 \\
(0.948)\end{array}$ \\
\hline $\begin{array}{l}\text { R-squared } \\
\text { No. obs. }\end{array}$ & $\begin{array}{l}0.00 \\
722\end{array}$ & $\begin{array}{l}0.01 \\
730\end{array}$ & $\begin{array}{l}0.00 \\
258\end{array}$ & $\begin{array}{l}0.01 \\
380\end{array}$ & $\begin{array}{l}0.01 \\
686\end{array}$ & $\begin{array}{l}0.02 \\
606\end{array}$ & $\begin{array}{l}0.01 \\
340\end{array}$ & $\begin{array}{c}0.12 \\
36\end{array}$ & $\begin{array}{c}0.03 \\
66\end{array}$ & $\begin{array}{l}0.02 \\
410\end{array}$ \\
\hline
\end{tabular}

The dependent variables are the percentages of failed tests in a particular subject. Variable Minority is a dummy indicating minority language schools and captures the difference between the treatment and control group at the baseline. Variable Year2010 is a dummy for the year 2010 and captures the time trend. Variable Minority*Year2010 is the interaction of variable Minority with variable Year2010 and shows the treatment effect. Constant term is included in regressions, but not reported. Cluster-robust standard errors are reported in parentheses. Asterisks denote significance levels: *** - significant at $1 \%$, ** - significant at $5 \%$ and * - significant at $10 \%$. 
Table 17. The effect of the language policy change on the average test scores, OLS and FE estimates.

\begin{tabular}{|c|c|c|c|c|c|c|c|c|c|c|}
\hline & " History & "Math & Physics & "Chemistry & Biology & "Geography & English & "French & German & "All languages \\
\hline Minority*Year2010 & $\begin{array}{c}1.165 \\
(1.271)\end{array}$ & $\begin{array}{c}4.554 * * * \\
(1.428)\end{array}$ & $\begin{array}{c}2.762 \\
(2.873)\end{array}$ & $\begin{array}{l}6.512^{*} \\
(3.399)\end{array}$ & $\begin{array}{c}2.046 \\
(1.784)\end{array}$ & $\begin{array}{c}-0.400 \\
(1.937)\end{array}$ & $\begin{array}{l}-0.359 \\
(2.200)\end{array}$ & $\begin{array}{c}5.049 \\
(8.373)\end{array}$ & $\begin{array}{l}-7.699 \\
(9.367)\end{array}$ & $\begin{array}{l}-1.192 \\
(1.944)\end{array}$ \\
\hline Minority & $\begin{array}{c}-14.180 * * * \\
(1.353)\end{array}$ & $\begin{array}{c}-12.829 * * * \\
(1.345)\end{array}$ & $\begin{array}{c}-9.794 * * * \\
(2.107)\end{array}$ & $\begin{array}{c}-14.348 * * * \\
(2.427)\end{array}$ & $\begin{array}{c}-12.600 * * * \\
(1.641)\end{array}$ & $\begin{array}{c}-8.067 * * * \\
(2.026)\end{array}$ & $\begin{array}{c}-5.467 * * \\
(2.246)\end{array}$ & $\begin{array}{l}-9.201 \\
(7.852)\end{array}$ & $\begin{array}{l}-3.186 \\
(5.754)\end{array}$ & $\begin{array}{c}-5.212 * * * \\
(1.851)\end{array}$ \\
\hline Year2010 & $\begin{array}{c}-1.991 * * * \\
(0.631)\end{array}$ & $\begin{array}{c}-6.344^{* * *} \\
(0.651)\end{array}$ & $\begin{array}{c}-2.572^{*} \\
(1.515)\end{array}$ & $\begin{array}{c}-4.661^{* * * *} \\
(1.208)\end{array}$ & $\begin{array}{l}-0.965 \\
(0.813)\end{array}$ & $\begin{array}{l}-1.024 \\
(0.695)\end{array}$ & $\begin{array}{l}-0.198 \\
(0.809)\end{array}$ & $\begin{array}{l}-8.556 \\
(6.703)\end{array}$ & $\begin{array}{c}-11.874 * * * \\
(2.627)\end{array}$ & $\begin{array}{c}-1.406^{*} \\
(0.829)\end{array}$ \\
\hline Town & $\begin{array}{c}2.045 \\
(1.849)\end{array}$ & $\begin{array}{c}9.095 * * * \\
(2.361)\end{array}$ & $\begin{array}{c}1.751 \\
(5.817)\end{array}$ & $\begin{array}{c}9.821 * * \\
(3.906)\end{array}$ & $\begin{array}{c}8.459 * * * \\
(2.232)\end{array}$ & $\begin{array}{c}5.163 \\
(3.227)\end{array}$ & $\begin{array}{c}1.465 \\
(4.379)\end{array}$ & & $\begin{array}{c}4.325 \\
(8.323)\end{array}$ & $\begin{array}{c}1.317 \\
(4.508)\end{array}$ \\
\hline City & $\begin{array}{c}2.247 * * \\
(0.878)\end{array}$ & $\begin{array}{c}3.989 * * * \\
(0.965)\end{array}$ & $\begin{array}{c}5.649 * * \\
(2.677)\end{array}$ & $\begin{array}{c}5.142 * * * \\
(1.669)\end{array}$ & $\begin{array}{c}3.300 * * \\
(1.319)\end{array}$ & $\begin{array}{c}0.283 \\
(1.161)\end{array}$ & $\begin{array}{l}2.506^{*} \\
(1.502)\end{array}$ & $\begin{array}{c}-12.564 * * \\
(5.656)\end{array}$ & $\begin{array}{l}-4.267 \\
(2.909)\end{array}$ & $\begin{array}{l}1.929 \\
(1.404)\end{array}$ \\
\hline Gymnasium & $\begin{array}{c}13.609 * * * \\
(1.808)\end{array}$ & $\begin{array}{c}11.568 * * * \\
(2.587)\end{array}$ & $\begin{array}{c}18.485^{* * *} * \\
(2.116)\end{array}$ & $\begin{array}{c}10.183 * * * \\
(2.574)\end{array}$ & $\begin{array}{c}12.563 * * * \\
(3.289)\end{array}$ & $\begin{array}{c}10.435 * * * \\
(2.369)\end{array}$ & $\begin{array}{c}14.085 * * * \\
(2.185)\end{array}$ & $\begin{array}{c}13.289 * * * \\
(3.574)\end{array}$ & $\begin{array}{l}6.861^{*} \\
(3.921)\end{array}$ & $\begin{array}{c}13.260 * * * \\
(2.092)\end{array}$ \\
\hline Lyceum & $\begin{array}{c}6.544 * * * \\
(1.674)\end{array}$ & $\begin{array}{c}10.606 * * * \\
(1.723)\end{array}$ & $\begin{array}{c}13.766^{* * *} \\
(3.735)\end{array}$ & $\begin{array}{l}4.954 * \\
(2.533)\end{array}$ & $\begin{array}{c}6.879 * * * \\
(2.274)\end{array}$ & $\begin{array}{c}5.850 * * * \\
(1.952)\end{array}$ & $\begin{array}{c}5.016^{* * *} \\
(1.506)\end{array}$ & $\begin{array}{c}10.716^{* *} \\
(4.487)\end{array}$ & $\begin{array}{c}5.621 \\
(6.225)\end{array}$ & $\begin{array}{c}5.020 * * * \\
(1.473)\end{array}$ \\
\hline Specialized school & $\begin{array}{c}6.668 * * * \\
(1.980)\end{array}$ & $\begin{array}{c}5.032 * * \\
(2.002)\end{array}$ & $\begin{array}{c}3.747 \\
(2.787)\end{array}$ & $\begin{array}{c}6.022 * * \\
(2.699)\end{array}$ & $\begin{array}{c}10.909 * * * \\
(2.541)\end{array}$ & $\begin{array}{c}2.652 \\
(2.547)\end{array}$ & $\begin{array}{c}13.788 * * * \\
(2.666)\end{array}$ & $\begin{array}{c}17.770 \\
(18.471)\end{array}$ & $\begin{array}{c}23.640 * * * \\
(2.646)\end{array}$ & $\begin{array}{c}14.654^{* * * *} \\
(2.408)\end{array}$ \\
\hline Special school & $\begin{array}{c}5.353 \\
(5.387)\end{array}$ & $\begin{array}{c}8.329 \\
(6.690)\end{array}$ & $\begin{array}{l}-5.525 \\
(4.455)\end{array}$ & $\begin{array}{c}6.521^{* *} \\
(3.114)\end{array}$ & $\begin{array}{c}-0.851 \\
(5.954)\end{array}$ & $\begin{array}{c}4.513 \\
(7.144)\end{array}$ & $\begin{array}{c}12.240 * * \\
(6.049)\end{array}$ & & $\begin{array}{c}0.754 \\
(7.858)\end{array}$ & $\begin{array}{l}10.181 \\
(6.418)\end{array}$ \\
\hline Boarding school & $\begin{array}{c}0.574 \\
(2.619)\end{array}$ & $\begin{array}{l}-3.075 \\
(2.220)\end{array}$ & $\begin{array}{l}-4.168 \\
(4.009)\end{array}$ & $\begin{array}{c}-8.897 * * * \\
(2.946)\end{array}$ & $\begin{array}{l}-3.445 \\
(2.459)\end{array}$ & $\begin{array}{l}-1.825 \\
(3.100)\end{array}$ & $\begin{array}{l}-4.679 \\
(4.262)\end{array}$ & $\begin{array}{c}-7.260 * * \\
(3.422)\end{array}$ & $\begin{array}{l}-10.478 \\
(6.618)\end{array}$ & $\begin{array}{l}-4.401 \\
(4.395)\end{array}$ \\
\hline $\begin{array}{l}\text { R-squared } \\
\text { No. obs. }\end{array}$ & $\begin{array}{l}0.41 \\
771\end{array}$ & $\begin{array}{l}0.37 \\
770\end{array}$ & $\begin{array}{l}0.28 \\
399\end{array}$ & $\begin{array}{l}0.20 \\
514\end{array}$ & $\begin{array}{l}0.27 \\
743\end{array}$ & $\begin{array}{l}0.13 \\
686\end{array}$ & $\begin{array}{l}0.39 \\
427 \\
\end{array}$ & $\begin{array}{c}0.15 \\
71\end{array}$ & $\begin{array}{l}0.45 \\
134 \\
\end{array}$ & $\begin{array}{c}0.39 \\
530\end{array}$ \\
\hline \multicolumn{11}{|l|}{ Panel B: FE estimates. } \\
\hline & $\begin{array}{l}\text { History } \\
\end{array}$ & Math & Physics & Chemistry & - Biology & " Geography & "English & French & German & "All languages \\
\hline Minority*Year2010 & $\begin{array}{c}1.247 \\
(1.254)\end{array}$ & $\begin{array}{c}4.355^{* * *} \\
(1.506)\end{array}$ & $\begin{array}{c}2.922 \\
(2.775)\end{array}$ & $\begin{array}{c}7.689 * * \\
(3.566)\end{array}$ & $\begin{array}{c}1.283 \\
(1.787)\end{array}$ & $\begin{array}{c}2.049 \\
(2.231)\end{array}$ & $\begin{array}{l}-2.355 \\
(2.487)\end{array}$ & $\begin{array}{c}9.046 \\
(5.731)\end{array}$ & $\begin{array}{l}-5.515 \\
(9.914)\end{array}$ & $\begin{array}{l}-2.210 \\
(1.883)\end{array}$ \\
\hline Year2010 & $\begin{array}{c}-2.163^{* * *} \\
(0.628)\end{array}$ & $\begin{array}{c}-6.363^{* * *} \\
(0.611)\end{array}$ & $\begin{array}{c}-3.796 * * \\
(1.677)\end{array}$ & $\begin{array}{c}-5.252^{* * *} \\
(1.243)\end{array}$ & $\begin{array}{l}-1.026 \\
(0.808)\end{array}$ & $\begin{array}{c}-2.143^{* * *} \\
(0.780)\end{array}$ & $\begin{array}{l}-0.220 \\
(0.891)\end{array}$ & $\begin{array}{c}-12.875^{* * *} \\
(3.081)\end{array}$ & $\begin{array}{c}-12.838^{* * *} \\
(3.452)\end{array}$ & $\begin{array}{l}-1.411 \\
(0.874)\end{array}$ \\
\hline R-squared & 0.04 & 0.26 & 0.04 & 0.09 & 0.01 & 0.03 & 0.01 & 0.11 & 0.37 & 0.03 \\
\hline
\end{tabular}

The dependent variables are the average scores in a particular subject. Variable Minority is a dummy indicating minority language schools and captures the difference between the treatment and control group at the baseline. Variable Year2010 is a dummy for the year 2010 and captures the time trend. Variable Minority*Year2010 is the interaction of variable Minority with variable Year2010 and shows the treatment effect. Constant term is included in regressions, but not reported. Cluster-robust standard errors are reported in parentheses. Asterisks denote significance levels: *** - significant at $1 \%$, ** - significant at $5 \%$ and * - significant at $10 \%$. 